\title{
Percepcja procesu dezintegracji Socjalistycznej Federacyjnej Republiki Jugosławii w administracji George'a H. W. Busha (do czerwca 1991 r.)
}

Po II wojnie światowej w wyniku rywalizacji supermocarstw, Stanów Zjednoczonych i Związku Radzieckiego, powstały dwa bloki, oddzielone od siebie ,żelazną kurtyną" Ten zimnowojenny porządek międzynarodowy, pomimo zmian i ewolucji, przetrwał de facto do końca lat 80 . XX w. ${ }^{1}$ W roku 1989, nazywanym później „rokiem cudów” (annus mirabilis) ${ }^{2}$, miały miejsce kluczowe wydarzenia dla Europy Wschodniej, które doprowadziły do upadku bloku państw podporządkowanych Moskwie, a także do polepszenia relacji

${ }^{1}$ Więcej o „zimnej wojnie” zob. np.: J.L. Gaddis, Zimna wojna. Historia podzielonego świata, tłum. B. Pietrzyk, Kraków 2007; J. Holzer, Europa zimnej wojny, Kraków 2012; Zimna wojna (1946-1989) $i$ jej konsekwencje dla tadu międzynarodowego, pod red. B. Koszela i S. Wojciechowskiego, Poznań 2007; W. Malendowski, Zimna wojna. Sprzeczności, konflikty $i$ punkty kulminacyjne $w$ radziecko-amerykańskiej rywalizacji, Poznań 1994.

${ }^{2}$ R. Kuźniar, Pozimnowojenne dwudziestolecie 1989-2010. Stosunki międzynarodowe na przełomie XX $i$ XXI wieku, Warszawa 2011, s. 9; R. Zenderowski, Wstę, [w:] Zjawiska i procesy dezintegracji w postzimnowojennej Europie, red. A. Rudowski, R. Zenderowski, Warszawa 2009 , s. 7. 
pomiędzy Wschodem i Zachodem oraz do zakończenia „zimnej wojny"3. Proces ten był możliwy dzięki wcześniejszym zmianom na szczytach władzy w ZSRR, gdy w 1985 r. na czele partii stanął Michaił Gorbaczow, pragnacy przeprowadzić potrzebne w tym kraju reformy ${ }^{4}$. Kreml ograniczył kontrolę nad swymi satelitami, w których coraz głośniej mówiło się o zmianach i stopniowej demokratyzacji, a także doprowadził do odprężenia w stosunkach z Zachodem.

Efektem tego były m.in. wydarzenia z „roku cudów”, jak chociażby rozmowy „okragłego stołu” i wybory 4 czerwca 1989 r. w Polsce, ,jesień narodów” i stopniowe przejmowanie władzy przez opozycję w kolejnych państwach Europy Wschodniej, upadek muru berlińskiego oraz krwawe obalenie Nicolae Ceauşescu w Rumunii. Wkrótce przestały istnieć Układ Warszawski i Rada Wzajemnej Pomocy Gospodarczej oraz doszło do zjednoczenia Niemiec. Rozpoczą się proces transformacji państw, które przez wiele lat pozostawały po wschodniej stronie „żelaznej kurtyny”. Równolegle można

${ }^{3}$ Więcej na ten temat zob. np.: A. Burakowski, A. Gubrynowicz, P. Ukielski, 1989 - Jesień Narodów, Warszawa 2009; V. Sebestyen, Rewolucja 1989. Jak doszło do upadku komunizmu, Wrocław 2009; J. Stańczyk, Kres „zimnej wojny”. Bezpieczeństwo europejskie w procesie zmiany międzynarodowego układu sit (na przełomie lat osiemdziesiatych i dziewięćdziesiatych XX w.), Torun 2004; J. Gorzkowski, W. Morawski, Jesień narodów, Warszawa 1991; T. Garton Ash, Wiosna obywateli. Rewolucja 1989 widziana $w$ Warszawie, Budapeszcie, Berlinie i Pradze, Londyn 1990.

${ }^{4}$ Zob. więcej: R.G. Pichoja, Historia władzy $w$ Zwiazku Radzieckim 1945-1991, tł. M. Głuszkowski, P. Zemszał, Warszawa 2011, s. 453 i nast.; V. Zubok, Nieudane imperium. Zwiazek Radziecki okresu zimnej wojny, od Stalina do Gorbaczowa, tłum. A. Czwojdrak, Kraków 2010, s. 268 i nast.; L. Bazylow, P. Wieczorkiewicz, Historia Rosji, wyd. 4 popr. i uzup., Wrocław 2005, s. 537-559. 
było zaobserwować zmianę w relacjach pomiędzy Waszyngtonem a Moskwa, oznaczająca de facto zakończenie zimnowojennej rywalizacji. Na fali entuzjazmu niektórzy głosili nawet hasła „końca historii”.

Wydarzenia te zbiegły się w czasie ze zmiana gospodarza Białego Domu. 20 stycznia 1989 r. George Herbert Walker Bush został 41. prezydentem Stanów Zjednoczonych Ameryki $^{6}$. Ten były pilot bombowca z okresu II wojny światowej posiadał bogate doświadczenie polityczne. Swą karierę rozpoczą w latach 60. jako przedstawiciel partii republikańskiej w Izbie Reprezentantów, a w latach 70. pełniąc funkcje m.in.: ambasadora USA przy Narodach Zjednoczonych, szefa amerykańskiej misji łącznikowej w Pekinie, dyrektora Centralnej Agencji Wywiadowczej (CIA). Natomiast po wygranych wyborach prezydenckich przez Ronalda Reagana w 1980 i 1984 r., Bush przez dwie kadencje był wiceprezydentem Stanów Zjednoczonych. Reagan poparł swego zastępcę w wyborach w 1988 r. i opisał go jako człowieka, który nie obawia się wyrażać swoich pogladów i który nie unika walki, nigdy nie wycofuje się ze swoich przekonań $i$ nigdy nie usprawiedliwia swojego postepowania ${ }^{7}$. Ostatecznie kampania prezydencka zakończyła się wyraźnym zwycięstwem przedstawiciela republikanów nad kandydatem demokratów - Michaelem Dukakisem.

${ }^{5}$ Amerykański badacz Francis Fukuyama opublikował wówczas głośny esej pod tytułem Koniec historii?, rozwinięty później do formy książki.

${ }^{6}$ Więcej nt. G. Busha zob.: L. Pastusiak, Prezydenci Stanów Zjednoczonych Ameryki, Warszawa 2005, s. 981-1019; idem, George Bush. 41 prezydent Stanów Zjednoczonych A.P., Warszawa 1989; G. Bush, V. Gold, Patrzqc w przyszłość. Autobiografia, Gdańsk 1990; G. Bush, B. Scowcroft, Świat przekształcony, przeł. J.J. Górski, Warszawa 2000; G. Bush, All the best, George Bush. My life in letters and other writings, New York 1999.

${ }^{7}$ L. Pastusiak, Prezydenci Stanów..., s. 988. 
Bush, obejmując ster rządów w Białym Domu, zdawał sobie sprawę, posiadając doświadczenie z pracy w administracji, jak ważne znaczenie - dla prowadzenia polityki zagranicznej - ma dobór dobrze przygotowanych specjalistów i członków gabinetu. Nowy prezydent chciał także mieć w swym otoczeniu osoby nieprzeciętne, które znał i na których lojalności mógł polegać. Funkcję sekretarza stanu obją wieloletni przyjaciel rodziny Bushów - prawnik James Baker III. Kierował on zwycięską kampania prezydencka w 1988 r., a w administracji Reagana był szefem personelu Białego Domu i sekretarzem skarbu. Zastępca Bakera w Departamencie Stanu został dyplomata Lawrence Eagleburger. Stanowisko doradcy do spraw bezpieczeństwa narodowego powierzono niezwykle doświadczonemu Brentowi Scowcroftowi (na tym stanowisku pracował u Geralda Forda w latach 1975-1977), sekretarzem obrony mianowano wieloletniego kongresmana Richarda Cheneya, który pełnił funkcje m.in. członka Specjalnej Komisji ds. Wywiadu, a także szefa personelu Białego Domu w okresie prezydentury G. Forda. Inne, ważne z punktu widzenia polityki zagranicznej, postaci w ekipie Busha to: gen. Colin Powell (od października 1989 r. Przewodniczacy Kolegium Połączonych Szefów Sztabu) oraz Robert Gates - zastępca doradcy ds. bezpieczeństwa narodowego, a od listopada 1991 r. dyrektor CIA. Jak zauważył B. Scowcroft, wybrana przez prezydenta ekipa okazata się zespotem bardzo ściśle zwiqzanych ze soba ludzi. Większość z nich wcześniej już razem pracowata $i$ wniosła do nowej administracji olbrzymie doświadczenie. Charakteryzowato nas głębokie poczucie koleżeństwa ${ }^{8}$. W tym zespole najważniejszy w kwestiach polityki zagranicznej był triumwirat: Bush, Scowcroft, Baker 9

${ }^{8}$ G. Bush, B. Scowcroft, op. cit., s. 36.

${ }^{9} \mathrm{~S}$. Hurst, The Foreign Policy of the Bush Administration. In Search of a New World Order, London-New York 1999, s. 14. 
Longin Pastusiak, opisując politykę zagraniczną Busha, stwierdza, że cechowało ją osobiste zaangażowanie prezydenta połaczone $z$ ostrożnościa, rozwaga $i$ pragmatyzmem. Rozwaga Busha byta tak widoczna, że krytycy zarzucali mu brak jakiejkolwiek wizji rozwiazania problemów międzynarodowych, zwłaszcza $w$ okresie rozpadu systemu dwubiegunowego $w$ stosunkach międzynarodowych [...]. Analitycy amerykańscy określali politykę zagraniczna Busha mianem reaktywnej, tzn. jedynie reagujacej na bieżqce wydarzenia. [...] Bush lubit określać swoja politykę zagraniczna mianem status quo plus ${ }^{10}$. Warto także pamiętać, że pewną rolę w dziedzinie polityki zagranicznej USA odgrywa Kongres, a podczas rządów republikańskiego prezydenta większość w jego obu izbach posiadali demokraci ${ }^{11}$.

Nowa administracja amerykańska musiała zmierzyć się z szeregiem problemów w skali światowej ${ }^{12}$. W początkowej fazie procesu przemian, zachodzacych w stosunkach międzynarodowych, i końca „zimnej wojny”, Stany Zjednoczone nie

${ }^{10}$ L. Pastusiak, Prezydenci..., s. 1003.

${ }^{11}$ K. Michałek, Mocarstwo. Historia Stanów Zjednoczonych Ameryki 1945-1992, Warszawa 1995, s. 470; G. Bush, B. Scowcroft, op. cit., s. 42.

${ }^{12}$ Więcej o polityce zagranicznej administracji G. Busha zob.: K. Michałek, Amerykańskie stulecie. Historia Stanów Zjednoczonych Ameryki 1900-2001, Warszawa 2004, s. 673-690; P. Matera, R. Matera, Stany Zjednoczone i Europa. Stosunki polityczne i gospodarcze 1776-2004, Warszawa 2007, s. 314-328; T.H. Henriksen, American Power after the Berlin Wall, New York 2007, s. 5 i nast.; S. Hurst, op. cit.; From Cold War to New World Order. The Foreign Policy of George H.W. Bush, ed. by M. Bose and R. Perotti, Westoport-London 2002; S. Vanhoonacker, Bush Administration (19891993) and the Development of a European Security Identity, Aldershot 2001; J.A. Baker III (with T.M. DeFrank), The Politics of Diplomacy. Revolution, War and Peace 1989-1992, New York 1995; R.L. Hutchings, American Diplomacy and the End of the Cold War. An Insider's Account of U.S. Diplomacy in Europe, 1989-1992, Washington-Baltimore-London 1997. 
posiadały sformułowanego wyraźnie „dekalogu” celów w polityce zagranicznej. Kres zimnowojennej rywalizacji przyczynił się do zniknięcia zagrożenia globalnym konfliktem pomiędzy dwoma ówczesnymi supermocarstwami i dwoma dominujacymi na scenie międzynarodowej blokami państw, jak również widma nuklearnej zagłady. W nowej rzeczywistości przedstawiciele administracji G. Busha opowiadali się za kontynuacja polityki zaangażowania Ameryki na arenie międzynarodowej, w tym również w Europie. Sekretarz stanu J. Baker oświadczył w grudniu 1989 r., iż Stany Zjednoczone sq i pozostana mocarstwem europejskim, a nowa architektura europejska powinna uwzględniać polityczne, wojskowe $i$ gospodarcze zwiazki ze Stanami Zjednoczonymi ${ }^{13}$.

Koniec konfrontacji obozów oraz stopniowy demontaż bloku wschodniego stwarzały nowe podstawy polityki wspierania demokratyzacji dawnych krajów satelickich Moskwy ${ }^{14}$. Amerykanie początkowo podchodzili jednak ostrożnie do wydarzeń w Europie Wschodniej i byli zaskoczeni tempem przemian ${ }^{15}$. Amerykański prezydent i jego doradcy obawiali się bowiem zbyt gwałtownych zmian $\mathrm{w}$ rozpadającym się bloku

${ }^{13}$ Cyt. za: J. Kiwerska, Rozchodzenie się dwóch światów? Stany Zjednoczone i relacje transatlantyckie 1989-2012, Poznań 2013, s. 21.

${ }^{14} \mathrm{G}$. Nycz, Amerykańska polityka wspierania demokracji $w$ Europie Wschodniej w latach 1989-1991, „Przegląd Zachodni” 2010, nr 1, s. 219.

${ }^{15}$ Zob. więcej: G. Bush, B. Scowcroft, op. cit., s. 58 i nast.; K. Michałek, Mocarstwo..., s. 479; idem, Ku zmianie amerykańskiej strategii wobec Europy Wschodniej: administracja George'a Busha seniora wobec Okragtego Stotu, [w:] Polski rok 1989. Sukcesy, zaniechania, porażki, [cz. 1], red. nauk. M. Jabłonowski, S. Stępka, S. Sulowski, Warszawa 2009, s. 483-488; G. Nycz, op. cit., s. 210; T. Blanton, Ronald Reagan, George H.W. Bush, and the Revolutions of 1989: U.S. Myths Versus the Primary Sources, [w:] Imposing, Maintaining, and Tearing Open the Iron Curtain. The Cold War and East-Central Europe, 1945-1989, ed. by M. Kramer and V. Smetana, Lanham 2014, s. 279 i nast. 
wschodnim. Pewien wpływ na taką strategię miały m.in. wydarzenia w Chinach. Wyzwaniem dla amerykańskiej polityki zagranicznej w pierwszym okresie prezydentury G. Busha była niewątpliwie konieczność odpowiedzi na krwawe stłumienie protestów chińskich studentów na pekińskim placu Tiananmen w czerwcu 1989 r. Prezydent zdawał sobie sprawę, iż wojska ZSRR są ciagle obecne w krajach bloku wschodniego $\mathrm{i}$, jak pisał w swoich wspomnieniach, niebezpieczeństwo byto przed nami $i$ w miare jak narody Europy Wschodniej torowaty sobie droge ku przyszłości, musiałem reagować z jeszcze większa ostrożnościq. Nie mogliśmy pozwolić, aby narody te poniosty klęskę, takich tragedii bowiem, jakie wydarzyty sie na placu Tiananmen, mogłoby być więcej ${ }^{16}$.

Bush dążył do zacieśnienia stosunków ze Związkiem Radzieckim i wzmocnienia dialogu strategicznego. Wierzył, że ZSRR przy odpowiednim podejściu Zachodu, może stać się sojusznikiem. Amerykanie starali się wspierać pokojowe przemiany polityczne i gospodarcze w rozpadającym się bloku wschodnim, jak również w Związku Radzieckim, pamiętając o olbrzymim arsenale broni jądrowej i o niebezpieczeństwie destabilizacji w regionie ${ }^{17}$. W grudniu $1989 \mathrm{r}$. amerykański prezydent przyznał, że USA są wstrzaśnięte

${ }^{16}$ G. Bush, B. Scowcroft, op. cit., s. 140. O niebezpieczeństwie zmian w Europie, a szczególnie na Bałkanach, mówił np. L. Eagleburger na wykładzie w Georgetown we wrześniu 1989 r., M.R. Beschloss, S. Talbott, At the Highest Levels: The Inside Story of the End of the Cold War, Boston 1993, s. 106.

${ }^{17}$ Jak zauważył Christopher Andrew: Na wiosne 1989 r. prezydent $i$ jego administracja, a nawet jego wywiad, nie ogarniali złożoności procesów zachodzacych $w$ socjalistycznym bloku. [...] Za radosnym spektaklem zrzucania komunistycznych pęt w państwach Europy Wschodniej-zarówno Bush, jak i analitycy z wywiadu - dostrzegali przerażajaca groźbę destabilizacji sowieckiej potegi nuklearnej, Ch. Andrew, Tylko dla oczu prezydenta, tłum. E. Żelazna, Warszawa 1998, s. 560, 562. 
tempem zmian, które dokonuja się $\mathrm{w}$ tej części kontynentu europejskiego, równocześnie zmieniając swe stanowisko w kwestii relacji Waszyngton-Moskwa. Stwierdził, że nie będzie podejmować działań, które mogtyby osłabić pozycje $\operatorname{Rosjan}^{18}$. Waszyngton popierał więc ekonomicznie i politycznie ekipę M. Gorbaczowa i uważał, że Kreml może stać się aktywnym partnerem $w$ dziele utrzymania bezpieczeństwa europejskiego, $w$ rozwiazywaniu lokalnych konfliktów, a takze $w$ walce $z$ rozprzestrzenianiem broni masowej zagtady ${ }^{19}$. Jednak równocześnie Amerykanów niepokoiła kwestia przyszłości ZSRR, który, jak się później okazało, był w trakcie procesu dezintegracji, zakończonego ostatecznie w grudniu 1991 r. I tutaj pojawia się pewien element łączący problem przyszłości Związu Radzieckiego oraz federacji jugosłowiańskiej. Nie można bowiem pomijać takiego czynnika, o czym pisał Paweł Chmielewski, jak swoistego „sprzężenia zwrotnego" między zjawiskami kryzysowymi w Jugostawii a destrukcja systemu politycznego rozpadajacego się Zwiazku Radzieckiego [...]. Kryzys batkański jakoś szczególnie „korespondowat" $z$ wydarzeniami wynikajacymi $z$ gorbaczowskiej „pierestrojki” $i$ z bezpośrednimi nastepstwami „aksamitnych rewolucji" w krajach Europy Środkowej i Wschodniej ${ }^{20}$. Ten „czynnik radziecki” będzie często pojawiał się w latach 1990-1991 w działaniach dyplomacji Stanów Zjednoczonych, obawiających się, iż ruchy odśrodkowe w federacji jugosłowiańskiej mogą oddziaływać na proces dezintegracji ZSRR,

18 J.L. Gaddis, op. cit., s. 289.

${ }^{19}$ Cyt. za: J. Kiwerska, Gra o Europę. Bezpieczeństwo europejskie w polityce Stanów Zjednoczonych pod koniec XX wieku, Poznań 2000, s. 258.

${ }^{20} \mathrm{P}$. Chmielewski, Konflikty bałkańskie pierwszej połowy lat 90. XX wieku w polityce Kremla, [w:] Bośnia i Hercegowina 15 lat po Dayton. Przeszłość - teraźniejszość - perspektywy. Studia i szkice, pod red. P. Chmielewskiego i S.L. Szczesio, Łódź 2011, s. 215. 
a może również Czechosłowacji ${ }^{21}$. Jak stwierdził Serhii Plokhy, największym zmartwieniem Białego Domu była wówczas groźba wojny domowej w Związku Radzieckim, gdyż nie chciano, aby dawne imperium carów stało sie „Jugostawia z atomówkami”, by użyć określenia, jakim postugiwaty się $w$ tamtym czasie gazety ${ }^{22}$.

Stany Zjednoczone starały się więc prowadzić ostrożną politykę „równowagi”, by nie doprowadzić do destabilizacji sytuacji w Europie. Równocześnie, w związku z osłabieniem pozycji Moskwy, USA stały się de facto jedynym supermocarstwem. Wydawało się wówczas, jak stwierdziła Jadwiga Kiwerska, że Ameryka przejmie $w$ tym momencie role ,żandarma" światowego. Tego zreszta oczekiwali sojusznicy i partnerzy Waszyngton $u^{23}$.

Latem 1990 r. Amerykanie zademonstrowali swoje możliwości $\mathrm{w}$ nowych warunkach postzimnowojennych. Bliski Wschód, w tym bogaty w złoża ropy naftowej rejon Zatoki Perskiej, stawał się coraz istotniejszy z punktu widzenia bezpieczeństwa gospodarczego i militarnego Stanów Zjednoczonych. Po agresji Iraku na Kuwejt (w sierpniu 1990 r.), powstała pod przewodnictwem Ameryki międzynarodowa koalicja przeciw Saddamowi Husajnowi. Liczyła kilkadziesiąt państw, a popierał ją także Związek Radziecki - co było

${ }^{21}$ Por.: M.J. Zacharias, Komunizm, federacja, nacjonalizmy. System wtadzy $w$ Jugostawii 1943-1991. Powstanie, przekształcenia, rozktad, Warszawa 2004, s. 546; R. Lukic, A. Lynch, Europe from the Balkans to the Urals. The Disintegration of Yugoslavia and the Soviet Union, New York 1996, s. 253; J. Headley, Russia and the Balkans. Foreign Policy from Yeltsin to Putin, London 2008, s. 61, 67 i nast.

${ }^{22}$ S. Plokhy, Ostatnie imperium. Historia upadku Zwiazku Sowieckiego, przekł. Ł. Witczak, Kraków 2015, s. 28.

${ }^{23}$ J. Kiwerska, Czas wielkich zawirowan, „Przegląd Zachodni” 2009, nr 1, s. 7 . 
egzemplifikacja końca „zimnej wojny”24. Ostatecznie siły koalicyjne wyzwoliły Kuwejt w lutym 1991 r., co było wielkim sukcesem Stanów Zjednoczonych ${ }^{25}$. Jak zauważyła J. Kiwerska: Bezsprzecznie byt to triumf amerykańskiej technologii, profesjonalizmu $i$ strategicznej wirtuozerii wojskowych. Ameryka potwierdziła swoja dominujaca role na arenie międzynarodowej, sprawdzita się tė̇ jako lider wolnego świata ${ }^{26}$.

A tak te wydarzenia opisywali amerykański prezydent G. Bush wraz ze swym doradca ds. bezpieczeństwa B. Scowroftem: Wojna $w$ Zatoce Perskiej stanowita swego rodzaju pomost między erq zimnowojenna a postzimnowojenna. Pierwsza konferencja prasowa Bakera i Szewardnadze ${ }^{27}$, podczas której Stany Zjednoczone i Zwiazek Radziecki zajęty wspólne stanowisko wobec agresji irackiej, miata znaczenie epokowe. Symbolizowata zmieniajace się stosunki sowiecko-amerykanskie. Wspótpraca supermocarstw otwierała perspektywy zbudowania świata, $w$ którym - w przeciwieństwie do minionych 40 lat - członkowie Rady Bezpieczeństwa mogli podejmować działania przeciwko agresji $w$ sposób przewidziany przez twórców Karty Narodów Zjednoczonych. [...] Stany Zjednoczone uznały i przyjęty szczególna odpowiedzialność za przywództwo $w$ rozwiazywaniu międzynarodowych sytuacji kryzysowych. Dla swojej kierowniczej roli uzyskały także szeroka aprobate

${ }^{24}$ Pisze o tym w swoich wspomnieniach np. J. Baker.

${ }^{25}$ Więcej o wojnie w Zatoce Perskiej zob.: G. Bush, B. Scowcroft, op. cit., s. 311-504; H.N. Schwarzkopf (współpr. P. Petre), Nie trzeba bohatera. Autobiografia, Warszawa 1993, s. 317-527; S. Tanner, Wojny Bushów. Ojciec i syn jako zwierzchnicy sit zbrojnych, przeł. J. Lang, Wrocław 2007, s. 61-106; K. Czornik, Irak w polityce zagranicznej Stanów Zjednoczonych w okresie pozimnowojennym, Katowice 2011, s. 112-159.

${ }^{26}$ J. Kiwerska, Czas wielkich..., s. 7.

${ }^{27}$ Eduard Szewardnadze - ówczesny minister spraw zagranicznych ZSRR. 
$w$ świecie. Wiarygodność polityczna i wptywy Stanów Zjednoczonych osiagnęty nienotowany dotad poziom. Podczas kryzysu $w$ Zatoce Perskiej zostaliśmy prawie sami na światowej scenie wydarzeń politycznych, korzystajac od czasu do czasu z bardzo powściagliwej pomocy Zwiazku Radzieckiego. [...] W konsekwencji znaleźliśmy się po wojnie w Zatoce Perskiej w świecie catkowicie odmienionym od tego, jaki istniat przed agresja iracka na Kuwejt ${ }^{28}$. Swój sukces administracja Busha starała się także wykorzystać, np. włączając się w bliskowschodni proces pokojowy i próbujac powstrzymać wieloletni konflikt palestyńsko-izraelski - niestety, bez powodzenia ${ }^{29}$.

Wojna z Irakiem pokazała ogromne możliwości amerykańskich sił zbrojnych i mogło się wydawać, że konflikt ten „wyleczył” Amerykanów z „kompleksu Wietnamu”. Stany Zjednoczone dysponowały dużą i nowoczesną armia, wyposażona w najnowsze technologie, która była w stanie działać w każdym zakątku świata. Chociaż mogłoby się wydawać, że nikt nie jest w stanie zagrozić potędze USA, to jednak Ameryka miała swoje problemy wewnętrzne, które - jak pisał Zbigniew Brzeziński - ograniczaja fizycznie zakres jej wtadzy $i$ utrudniaja przemianę tej wtadzy $w$ uznany autorytet światowy. W konsekwencji Stany Zjednoczone nie moga petnić funkcji stróża światowego porzqdku ani światowego bankiera, ani nawet światowego moralisty $^{30}$. Potwierdzeniem ograniczeń możliwości administracji amerykańskiej mogła być wspominana wojna z Irakiem, która przyniosła zwycięstwo militarne, jednak nie udało się

${ }^{28}$ G. Bush, B. Scowcroft, op. cit., s. 505.

${ }^{29}$ Więcej zob. J. Zając, Środki i metody oddziaływania USA $w$ bliskowschodnim procesie pokojowym (1991-2000), Warszawa 2004, s. 66 i nast.

${ }^{30}$ Z. Brzeziński, Bezład. Polityka światowa na progu XXI wieku, przekł. K. Murawski, Warszawa [1994], s. 131. Więcej o problemach i zagrożeniach wewnętrznych USA zob.: ibidem, s. 93 i nast.; L. Zyblikiewicz, USA, Warszawa 2004, s. 430-432. 
Waszyngtonowi osiagnąć satysfakcjonującego rozstrzygnięcia politycznego. Husajn nadal pozostawał przy władzy, a próby powstańcze szyitów i Kurdów zostały stłumione przez władze w Bagdadzie ${ }^{31}$. Z problemem irackim będą się jeszcze zmagać w przyszłości następcy Busha, w tym jego syn...

Równocześnie musimy pamiętać, że w USA odżyła debata na temat dalszej aktywnej polityki zagranicznej, w tym obecności tego państwa na kontynencie europejskim ${ }^{32}$, podobnie jak miało to miejsce po I i po II wojnach światowych. Wiele osób uważało, że Amerykanie musieli się angażować, kiedy istniało zagrożenie ze strony Związku Radzieckiego, natomiast po jego upadku lepiej było zajać się sprawami wewnętrznymi. Zaczęły bowiem pojawiać się objawy gospodarczych kłopotów Stanów Zjednoczonych od 1990 r., gdy zajęty polityką zagraniczna prezydent, nie podją skutecznych działań antyrecesyjnych ${ }^{33}$. Wzmogło to tendencje izolacjonistyczne w państwie amerykańskim.

Powstała wówczas konieczność opracowania nowej koncepcji polityki zagranicznej USA, a G. Bush zaczął mówić o „nowym ładzie światowym” (new world order) ${ }^{34}$. Amerykański przywódca widział świat wolny od groźby

${ }^{31}$ Z. Brzeziński, Bezład..., s. 140.

${ }^{32}$ Wiecej na ten temat zob.: J. Kiwerska, Gra..., s. 17-86; J. Zając, Koncepcje polityki zagranicznej USA po zimnej wojnie, [w:] Polityka zagraniczna USA po zimnej wojnie, red. nauk. J. Zając, Torun 2005, s. 15-19.

${ }^{33}$ Więcej o kłopotach gospodarczych USA w tym okresie zob. K. Michałek, Mocarstwo..., s. 472-474.

${ }^{34}$ Bush od lata 1990 r. do marca 1991 r. aż 43 razy użył w swoich wystapieniach pojęcia new world order, a terminem tym często posługiwali się także J. Baker i B. Scowcroft, Światowy ład i nieład, 4 III 2002, http://www. tygodnikprzeglad.pl/swiatowy-lad-nielad/ (dostęp 10 I 2015). Zob. także B.H. Sparrow, Realism's Practitioner: Brent Scowcroft and the Making of the New World Order, 1989-1993, „Diplomatic History” 2010, vol. 34, no. 1, s. $173-174$. 
terroru, w pogoni za sprawiedliwością i bardziej bezpieczny w poszukiwaniu pokoju, w którym narody uznaja wspólna odpowiedzialność za zachowanie wolności $i$ sprawiedliwości, a silni szanuja prawa stabszych ${ }^{35}$. Oficjalnie program ten został ogłoszony 6 marca 1991 r. i według J. Kiwerskiej: Mówiqa najkrócej, chodzito o zastapienie globalnej rywalizacji amerykańsko-radzieckiej wspótpraca wielostronna pod przywództwem Stanów Zjednoczonych. Była więc to próba połaczenia idei unilateralizmu z multilateralizmem. A zarazem pogodzenie światowych aspiracji Ameryki z jej ówczesnymi możliwościami ${ }^{36}$.

Jednak priorytetami polityki zagranicznej Waszyngtonu na początku lat 90 . XX w. było zaangażowanie na Bliskim Wschodzie, obserwacja wydarzeń w rozpadającym się Związku Radzieckim i proces zjednoczenia Niemiec ${ }^{37}$. Chociaż prezydent USA mówił o „nowym ładzie światowym”, a potwierdzeniem potęgi i znaczenia Stanów Zjednoczonych stała się wojna z Irakiem, to jednym z zagadnień, które miało absorbować uwagę państw europejskich, jak również administracji amerykańskiej, w tej nowej postzimnowojennej rzeczywistości, była dezintegracja Jugosławii.

${ }^{35}$ Zob.: Toward a New World Order, President Bush, Address before a joint session of Congress, Washington, DC, 11 IX 1990, „US Department of State Dispatch", 17 IX 1990, vol. 1, no. 3, s. 91-92; G. Bush, B. Scowcroft, op. cit., s. 380-381. Założenia „nowego ładu światowego” znalazły się w wystapieniach Busha we wrześniu 1990 r. i w styczniu 1991 r., J. Zając, Koncepcje polityki..., s. 20-21.

${ }^{36}$ J. Kiwerska, Gra..., s. 39.

${ }^{37}$ R. Vukadinović, U.S. Policy in the Southeast Europe, „Politička misao" 1998, vol. XXXV, no. 5, s. 90; Z. Brzeziński, Druga szansa, przeł. M. Szubert, Warszawa 2008, s. 43 i nast.; J. Western, U.S. Policy and Human Rights in Bosnia. The Transformation of Strategic Interests, [w:] Implementing U.S. Human Rights Policy. Agendas, Policies, and Practices, ed. D. Liang-Fenton, Washington 2004, s. 222-223. 
Federacja jugosłowiańska po II wojnie światowej znalazła się po wschodniej stronie ,żelaznej kurtyny”, występując przez kilka lat - według ówczesnych zachodnich mediów - jako satelita numer jeden Moskwy ${ }^{38}$. Po konflikcie Tito-Stalin kraj ten został uznany za „buntownika” w bloku podporządkowanym ZSRR, nie zgodził się jednak na opowiedzenie się po stronie Zachodu. Josip Broz-Tito jako współtwórca ruchu państw niezaangażowanych prowadził Jugosławię „trzecią droga”, balansując pomiędzy dwoma rywalizującymi ze sobą obozami ${ }^{39}$. Jednak kraj ten, chociaż pozornie silny i stabilny, nie był wolny od różnorakich problemów i kryzysów, czy to w wymiarze ekonomicznym, społecznym, czy narodowościowym. Jeszcze za życia Tity w Socjalistycznej Federacyjnej Republice Jugosławii (SFRJ) ${ }^{40}$ pogorszyła się sytuacja ekonomiczna, a także pojawiły się napięcia na tle narodowościowym, zwłaszcza w Kosowie i w Chorwacji. W 1980 r. zmarł wieloletni przywódca państwa, który potrafił „żelazną ręką" panować nad państwem tworzonym przez wiele narodów, z trudną przeszłościa, zwłaszcza w okresie II wojny światowej. Chociaż w porównaniu np. do krajów bloku wschodniego, obywatelom Jugosławii żyło się stosunkowo dobrze, a wielu zapewniało o wierności wobec systemu i państwa, wykrzykując hasła: Po śmierci Tity - Tito, to,

${ }^{38}$ Por.: M. Dijlas, Rise and Fall, London 1985, s. 82; R. West, Tito and the Rise and Fall of Yugoslavia, New York 1995, s. 217.

${ }^{39}$ Więcej zob. np.: M. Dymarski, „Miękkie podbrzusze Europy” - Batkany w nowoczesnych stosunkach międzynarodowych, [w:] Wprowadzenie do studiów wschodnioeuropejskich, t. 1, Batkany: przeszłość, teraźniejszość, przysztość, red. nauk. M. Podolak, Lublin 2013, s. 374-376; J.C. Campbell, Tito's Separate Road. America and Yugoslavia in World Politics, New York 1967; S. Rajak, Yugoslavia and the Soviet Union in the Early Cold War. Reconciliation, Comradeship, Confrontation, 1953-1957, London 2011.

${ }^{40}$ Nazwa ta została wprowadzona w 1963 r., W. Szczepański, Jugostawia, [w:] Vademecum batkanisty. Lata 500-2007, red. I. Czamańska, Z. Pentek, Poznań 2009, s. 149. 
jak zauważył jugosłowiański polityk Raif Dizdarević, SFRJ stawała przed problemami ekonomicznej $i$ społecznej stagnacji, wewnętrznych relacji $w$ federacji $w$ impasie [...] $i$ towarzyszacych im zagrożeń dla stabilności i jedności kraju $u^{41}$. W latach 80. XX w. narody Jugosławii musiały zmierzyć się z narastającym kryzysem gospodarczym, wzrostem cen i inflacja, bezrobociem, spadkiem stopy życiowej itd..$^{42}$ Dodatkowo postępował proces wymiany elit politycznych i intelektualnych w SFRJ, gdyż odchodziło pokolenie współpracowników Tity, a do władzy zaczęli dochodzić młodsi ludzie, którzy, jak pisał Leslie Benson, posiadali szerokie zaplecze $w$ swoich ojczystych republikach i przemawiali jęzkiem nacjonalizmu ${ }^{43}$.

Czynnikiem, który miał decydujący wpływ na rozwój sytuacji $\mathrm{w}$ federacji jugosłowiańskiej po śmierci wieloletniego przywódcy, był serbsko-albański konflikt w Kosowie. Obszar ten, ważny dla Serbów ze względów historycznych, funkcjonował jako albańskie centrum naukowe i kulturalne w tzw. drugiej Jugosławii. Równocześnie, w wyniku wysokiego przyrostu naturalnego Albańczyków oraz wyjazdów Serbów i Czarnogórców, Kosowo stawało się coraz bardziej albańska prowincja ${ }^{44}$. Narastające nieporozumienia pomiędzy Serbami

${ }^{41}$ R. Dizdarević, From the Death of Tito to the Death of Yugoslavia, trans. S. Risaluddin, Sarajevo-Zagreb 2009, s. 56-57.

${ }^{42}$ Więcej o sytuacji w SFRJ w latach 80. zob. np.: Yugoslavia in the 1980 s, ed. by P. Ramet, Boulder-London 1985; B. Magaš, The Destruction of Yugoslavia. Tracking the Break-up 1980-92, London-New York 1993; H. Lyndall, Yugoslavia in Crisis, Oxford 1989; M. Moczała Korzeniewska, Proces politycznego $i$ społecznego rozpadu Jugosławii (SFRJ) $w$ drugiej połowie lat osiemdziesiatych XX wieku, „Politeja” 2005, nr 1 (3), s. 259-279.

${ }^{43}$ L. Benson, Jugosławia. Historia w zarysie, tł. B. Gutowska-Nowak, Kraków 2011, s. 186.

${ }^{44}$ Więcej o sytuacji w tej prowincji w latach 80. zob.: K. Pawłowski, Kosowo. Konflikt $i$ interwencja, Lublin 2008, s. 64-68; D. Gibas-Krzak, Serbsko-albański konflikt o Kosowo wXX wieku. Uwarunkowania-przebieg 
i Albańczykami wywoływały coraz większe zaniepokojenie w kraju, jak i za granica. „Problem kosowski” był w latach 80. jednym z ważniejszych tematów, poruszanych przez elity SFRJ, i zarzewiem kryzysu państwa oraz zagrożeniem dla jego stabilności ${ }^{45}$.

W Jugosławii coraz więcej osób wyrażało niezadowolenie z pogarszającej się sytuacji w kraju, co potęgowało radykalizację nastrojów, zwłaszcza w Serbii i Słowenii. Jak słusznie zauważył Michał Jerzy Zacharias, niewydolność gospodarcza $i$ konflikty narodowościowe oraz polityczne pobudzaty i pogtębiaty wielka fale krytyki ustroju jugosłowiańskiego, zaś wszelkie konflikty społeczne $i$ polityczne tatwo przeksztatcaty sie $w$ narodowe. Niewatpliwie byto to specyficzna cecha ustroju Jugosławii. W rezultacie osia coraz wyraźniejszych tarć, napięć $i$ konfliktów w Jugostawii stawaty się nie tyle sprzeczności między władzq i społeczeństwem, jak w środkowoeuropejskich krajach „realnego socjalizmu”, ile sprzeczności narodowe. To one będa prowadzić do stopniowego rozpadu porzqdku spoteczno-ustrojowego SFRJ ${ }^{46}$.

Dodatkowo coraz słabsza pozycję mieli przywódcy na szczeblu ogólnojugosłowiańskim, gdyż nie udało się znaleźć godnego następcę Broz-Tity, a system kolektywno-rotacyjny rządów okazał się niewypałem.

- konsekwencje, Toruń 2009, s. 129-151; M. Korzeniewska-Wiszniewska, Geneza konfliktu serbsko-albańskiego w Kosowie w latach 1968-1998 na tle wewnętrznej polityki Jugostawii - próba analizy, „Studia z Dziejów Rosji i Europy Środkowo-Wschodniej” 2008, t. XLIII, s. 200-209; N. Malcolm, Kosovo. A Short History, New York 1998, s. 334-348.

${ }^{45}$ Jak pisał w swoich wspomnieniach R. Dizdarević, gdy stawał na czele Prezydium SFRJ w 1988 r., Kosowo było jednym z najpoważniejszych problemów politycznych Jugosławii, a gdy odchodził po roku, okręg ten stał się prawdziwym siedliskiem zła jugosłowiańskiego kryzysu, R. Dizdarević, op. cit., s. 449.

${ }^{46}$ M.J. Zacharias, Komunizm..., s. 410, 433. 
Ważnym czynnikiem była też postawa władz i obywateli jednej z najbogatszych republik - Słowenii. Mając dobre stosunki gospodarcze i polityczne z krajami Europy Zachodniej, Słoweńcy, pod przywództwem Milana Kučana, coraz częściej wyrażali niezadowolenie z konieczności wspierania przez nich regionów słabiej rozwiniętych. Zaczęli domagać się zmian w funkcjonowaniu ich republiki i całej federacji. Słowenia była także zaniepokojona sytuacją w Kosowie, co wkrótce doprowadziło do ostrego sporu Lublany z Belgradem.

Pod koniec lat 80. coraz większą władzę i znaczenie miał przywódca Serbii Slobodan Milošević, który wykorzystując m.in. problem kosowski, zmiany konstytucji i walkę z biurokracja, przeją w wyniku tzw. rewolucji antybiurokratycznej kontrolę nad Kosowem, Wojwodiną i Czarnogórą ${ }^{47}$. W 1989 r. ponownie dramatyczne wydarzenia miały miejsce w Kosowie, gdzie przy użyciu siły Serbowie narzucali swoje rozwiązania i ograniczyli autonomię tego okręgu (jak i Wojwodiny). Albańczycy protestowali przeciw tym zmianom - rozpoczęła się swe-

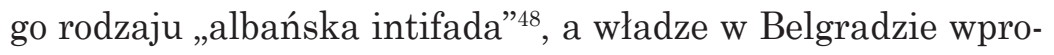
wadziły stan wyjątkowy. Jednak mimo to dochodziło w tej prowincji do demonstracji i starć sił porządkowych z ludnością albańska. Tymczasem Milošević wyrastał na bohatera serbskiego, faktycznie realizujac plany przywróceniu Serbii dwóch obwodów autonomicznych. Potwierdzeniem jego popularności były uroczystości z okazji 600-lecia bitwy na Kosowym Polu 28 czerwca 1989 r., które zgromadziły wielotysięczne tłumy,

${ }^{47}$ Więcej zob.: M. Korzeniewska-Wiszniewska, Serbia pod rzqdami Slobodana Miloševicia. Serbska polityka wobec rozpadu Jugostawii w latach dziewięćdziesiatych XX wieku, Kraków 2008, s. 68 i nast.; N. Vladisavljević, Serbia's Antibureaucratic Revolution. Milošević, the Fall of Communism and Nationalist Mobilization, Houndmills 2008; D. Jović, Yugoslavia: A State that Withered Away, West Lafayette 2009, passim.

${ }^{48}$ T. Judah, Kosovo. War and Revenge, New Haven-London 2000, s. 55. 
witające owacyjnie swego lidera ${ }^{49}$. Wydarzenia w Kosowie i działania władz w Belgradzie budziły zaniepokojenie w innych częściach wielonarodowej federacji, jak również na Zachodzie, w tym w Ameryce.

W tym czasie pogłębiający się kryzys wewnętrzny w SFRJ starał się powstrzymać nowy premier, a precyzyjniej - przewodniczący Związkowej Rady Wykonawczej (SIV), którym został w marcu 1989 r. chorwacki polityk Ante Markovićso. Podją on działania mające powstrzymać pogarszająca się sytuację ekonomiczną kraju. W grudniu 1989 r. zdecydował się na działania podobne do „terapii szokowej” Leszka Balcerowicza w Polsce $^{51}$. Reformy te napotykały na opór w poszczególnych republikach, a najsilniejszy w Słowenii i Serbii. We wrześniu 1989 r. Słoweńcy wprowadzili zmiany do swojej konstytucji, przewidujace np. prawo republiki do wystapienia $\mathrm{z}$ federacji i nadrzędność prawa republikańskiego nad federalnym, co de facto oznaczało niezależność Słowenii ${ }^{52}$. Narastał konflikt serbsko-słoweński, a wkrótce kolejne problemy pojawiły się w Chorwacji, gdzie odżyły spory serbsko-chorwackie.

${ }^{49}$ R. Thomas, Serbia under Milošević. Politics in the 1990s, London 2000, s. 49-51. Zob. także A. Jagiełło-Szostak, Nacjonalizm w przemówieniach Slobodana Miloševicia, „Sprawy Narodowościowe” 2012, z. 41, s. $223-234$.

${ }^{50} \mathrm{~J}$. Wojnicki, Przeobrażenia ustrojowe państw postjugostowiańskich (1990-2003), Pułtusk 2003, s. 24-25.

${ }^{51}$ Więcej o programie reform Markovicia zob. np.: M.J. Zacharias, Komunizm..., s. 461-462; V. Meier, Yugoslavia. A History of its Demise, trans. by S.P. Ramet, New York 2005, s. 103 i nast.; J.R. Lampe, Yugoslavia as History. Twice There Was a Country, 2nd ed., Cambridge 2000, s. 355 i nast.; D. Jović, op. cit., s. 354 i nast.

${ }^{52} \mathrm{~J}$. Targalski, Kres jugokomunizmu. Mechanizmy demontażu komunizmu w Jugostawii na przyktadzie Stowenii i Serbii (1986-1991), Poznań 2011, s. 199; J.K. Cox, Slovenia. Evolving Loyalties, London-New York 2005, s. 78. 
Ważnym wydarzeniem w SFRJ stał się na początku 1990 r. rozpad partii komunistycznej, gdy jej XIV Kongres okazał się, jak stwierdziła Sabrina Petra Ramet, partyjnym łabędzi śpiewem ${ }^{53}$. Upadł jeden z głównych elementów systemu władzy w Jugosławii, a wkrótce - w wyniku konsultacji przewodniczących prezydiów republik jugosłowiańskich - osiagnięto porozumienie $\mathrm{w}$ sprawie wprowadzenia $\mathrm{w}$ federacji pluralizmu politycznego ${ }^{54}$. Dlatego pomiędzy kwietniem a grudniem 1990 r. odbyły się wybory republikańskie, w których wygrywały m.in. partie dążące do większego usamodzielnienia się, a nawet do oderwania od federacji poszczególnych republik ${ }^{55}$.

I tutaj trzeba zadać pytania: Jakie miejsce w polityce Waszyngtonu w tych przełomowych dla świata i Europy momentach zajmowała federacja jugosłowiańska? Czy Amerykanie wiedzieli o problemach wewnętrznych tego państwa, o narastającym kryzysie, a nawet o groźbie rozpadu wielonarodowego kraju? Czy we władzach Stanów Zjednoczonych były osoby kompetentne, zorientowane $\mathrm{w}$ skomplikowanej tematyce bałkańskiej, mogące podjąć decyzje o zaangażowaniu USA w rozwiązanie tego narastającego problemu na południu Europy?

W okresie „zimnej wojny” kolejne administracje amerykańskie starały się wykorzystywać geopolityczne i strategiczne znaczenie Jugosławii na południu Europy i wpływać

${ }^{53}$ S.P. Ramet, The Three Yugoslavias. State-Building and Legitimation, 1918-2005, Washington 2006, s. 340.

${ }^{54}$ W. Walkiewicz, Jugosławia. Państwa sukcesyjne, Warszawa 2009, s. 242.

${ }^{55}$ Więcej o wyborach w SFRJ w 1990 r. zob.: K. Krysieniel, Jugostawia na rozdrożu. Wybory do władz republikańskich w 1990 roku, „Studia Politicae Universitatis Silesiensis” 2011, no. 7, s. 162-180; J. Wojnicki, Proces instytucjonalizacji przemian ustrojowych w państwach postjugosłowiańskich, Pułtusk 2007, s. 269-284. 
na Titę, by trzymał się z dala od ZSRR. Dlatego Waszyngton wspierał integralność wielonarodowego państwa i przedstawiał jugosłowiański przykład jako model „innej drogi” dla krajów zależnych od Kremla ${ }^{56}$. Warren Zimmermann stwierdził, że politykę Stanów Zjednoczonych wobec federacji jugosłowiańskiej w okresie „zimnej wojny” można streścić w czterech słowach: niepodległość, jedność, integralność terytorialna $a^{57}$.

Amerykanie starali się utrzymywać dobre relacje z Jugosławią również po śmierci Tity, jednak brak wyrazistych i charyzmatycznych postaci we władzach SFRJ, pogarszająca się sytuacja wewnętrzna kraju, a także postępujące w drugiej połowie lat 80. XX w. odprężenie w relacjach Wschód-Zachód miały wpływ na osłabienie kontaktów Waszyngtonu z Belgra$\operatorname{dem}^{58}$. Federacja jugosłowiańska traciła więc uprzywilejowaną pozycję, którą utrzymywała przez lata w relacjach z Ameryka jako socjalistyczny „buntownik”.

Trzeba podkreślić, że w nowej administracji G. Busha znalazło się wielu dyplomatów, mających doświadczenie m.in. z pracy $\mathrm{w}$ Jugosławii i znających dobrze problematykę tego kraju i regionu ${ }^{59}$. Wśród nich do najważniejszych

${ }^{56}$ M.J. Zacharias, Międzynarodowe uwarunkowania rozpadu Jugostawii 1990-1991, „Dzieje Najnowsze” 2003, R. XXXV, nr 2, s. 133-135.

${ }^{57}$ W. Zimmermann, Yugoslavia: 1989-1996, [w:] U.S. and Russian Policymaking with Respect to the Use of Force, ed. by J.R. Azrael, E.A. Payin, Santa Monica 1996, s. 178.

${ }^{58}$ Więcej na ten temat zob. S.L. Szczesio, Relacje amerykańsko-jugostowiańskie $w$ latach osiemdziesiatych $X X w$. - zarys problemu, [w:] Wokót spraw trudnych, bolesnych i zapomnianych. Studia i szkice, pod red. E. Kowalczyk [et al.], Łódź 2014, s. 752-768.

${ }^{59} \mathrm{~W}$ Ameryce grupę tę nazywano ,jugosłowiańską mafią, Ž. Kovačević, Amerika i raspad Jugoslavije, Beograd 2007, s. 83. Niektórzy twierdzili także, iż powiązania wielu przedstawicieli administracji Busha z przywódcami z Belgradu miały wpływ na politykę USA wobec Jugosławii w latach 
osób należeli, wspominani już wcześniej: doradca prezydenta ds. bezpieczeństwa - B. Scowcroft (pracował w ambasadzie w Belgradzie w latach 1959-1961) ${ }^{60}$; zastępca sekretarza sta$\mathrm{nu}$ - L. Eagleburger (spędził w Jugosławii siedem lat, najpierw jako pracownik ambasady w latach 1961-1965, a następnie jako ambasador w latach 1977-1981; nazywano go Lawrence of Macedonia i Mr. Yugoslavia) ${ }^{61}$, a także asystent sekretarza stanu ds. europejskich z lat 1991-1993 - Thomas Niles (w ambasadzie USA w Belgradzie w latach 1963-1965). Za największego eksperta w tematyce jugosłowiańskiej uchodził Eagleburger. Dyplomata ten miał dobre relacje osobiste z wieloma politykami w Jugosławii, w tym z Miloševiciem, i odgrywał istotną rolę w latach 80 . w działaniach biznesowych pomiędzy SFRJ a USA, stojąc przez kilka lat na czele firmy Kissinger Associates, a także pomagając przy powstaniu prywatnego konsorcjum "The Friends of Yugoslavia”62.

W drugiej połowie lat 80. relacje Jugosławii ze Stanami Zjednoczonymi zaczęły się wyraźnie zmieniać, a od marca

1989-1991. Pisze o tym np. ówczesny ambasador USA w Watykanie Thomas Patrick Melady, T.P. Melady, The Ambassador's Story. The United States and the Vatican in World Affairs, Huntington 1994, s. 147.

${ }^{60}$ Więcej zob.: J. Paquin, A Stability-Seeking Power. U.S. Foreign Policy and Secessionist Conflicts, Montreal 2010, s. 71-73; I.H. Daalder, I.M. Destler, In the Shadow of the Oval Office. Profiles of the National Security Advisers and the Presidents they Served - from JFK to George W. Bush, New York 2009, s. 168 i nast.; R. Lukic, A. Lynch, op. cit., s. 311; B.H. Sparrow, Realism's Practitioner..., s. 145, 170.

${ }^{61}$ Zob.: D. Doder, L. Branson, Milosevic. Portrait of a Tyrant, New York 1999, s. 69, 105; D. Halberstam, War in a Time of Peace. Bush, Clinton, and the Generals, New York 2002, s. 25.

${ }^{62}$ Por.: J. Glaurdić, The Hour of Europe. Western Powers and the Breakup of Yugoslavia, New Haven-London 2011, s. 313; P. Glynn, Yugoblunder, „The New Republic", 24 II 1992, vol. 206, no. 8, s. 15-17; D. Halberstam, op. cit., s. 138. Zastępcą L. Eagleburgera w Kissinger Associates był B. Scowcroft. 
1989 r. nowym ambasadorem w SFRJ został W. Zimmermann $^{63}$. Zastapił on Johna Scanlana, którego wielu oskarżało o proserbskie nastawienie i wspieranie S. Miloševicia ${ }^{64}$. Przed wyjazdem z Ameryki W. Zimmermann spotkał się z L. Eagleburgerem, który wkrótce został zastępcą sekretarza stanu. Były ambasador instruował nowego wysłannika Ameryki, że chociaż Jugosławia i Bałkany pozostajq ważne dla interesów USA, to jednak federacja jugosłowiańska nie ma już takiego znaczenia geopolitycznego jak wcześniej - jako bufor między NATO a Układem Warszawskim. Nowy ambasador miał także potwierdzić, że Stany Zjednoczone będą nadal wspierać jedność, integralność terytorialną i niezależność Jugosławii $^{65}$. Jednak w nowej sytuacji w Europie dla Amerykanów istotne stawały się inne kwestie, takie jak: demokratyzacja (np. w krajach rozpadającego się bloku wschodniego, jak chociażby Polska czy Węgry); zmiany idące w stronę gospodarki rynkowej i przestrzeganie praw człowieka ${ }^{66}$. Zmieniał

${ }^{63} \mathrm{~W}$. Zimmermann, The Last Ambassador. A Memoir of the Collapse of Yugoslavia, „Foreign Affairs” 1995, vol. 74, no. 2, s. 3.

${ }^{64} \mathrm{P}$. Shoup, The Disintegration of Yugoslavia and Western Foreign Policy in the 1980s, [w:] State Collapse in South-Eastern Europe. New Perspectives on Yugoslavia's Disintegration, ed. by L.J. Cohen and J. Dragović-Soso, West Lafayette 2008, s. 338; V. Meier, op. cit., s. 39. Scanlan został później doradcą Milana Panicia, serbskiego biznesmana z USA, który w 1992 r. przez kilka miesięcy stał na czele rządu „nowej” Jugosławii. Więcej zob. M. Panić (with K.C. Murphy), Prime Minister for Peace. My Struggle for Serbian Democracy, Lanham 2015, passim.

${ }^{65}$ Jak stwierdził w 1999 r. W. Zimmermann, pod tymi hasłami kryło się stwierdzenie, że Ameryka popiera Jugosławię jako niezależny kraj od dominacji radzieckiej, Interview with Warren Zimmermann, Interviewed by: Charles Stuart Kennedy, Initial interview date: December 10, 1996, http://www.loc.gov (dostęp 1 XI 2014).

${ }^{66}$ W. Zimmermann, Origins of a Catastrophe. Yugoslavia and its Destroyers - America's Last Ambassador Tells What Happened and Why, New York 1996, s. 7-8; idem, The Last..., s. 2. 
się stosunek administracji oraz ambasady USA wobec władz w Belgradzie.

Amerykanów szczególnie niepokoiła sytuacja w Kosowie. Nowy ambasador USA w SFRJ od początku swej obecności w federacji zaczał krytykować Belgrad za łamanie praw człowieka w tej części Serbii. Informacje o tych problemach w Jugosławii odnotowywano np. w amerykańskich raportach Country Reports on Human Rights Practices ${ }^{67}$. Mocno zaangażowani w kwestię kosowską byli niektórzy kongresmani, np. Joseph DioGuardi, Alfonse Al D'Amato, Bob Dole, Joe Biden i Thomas (Tom) Lantos. W grupie tej, stosunkowo nielicznej, znaleźli się wpływowi przedstawiciele obu partii. Niewatpliwie wpływ na ich działalność miała diaspora albańska zamieszkująca Stany Zjednoczone, która starała się pomóc swoim współziomkom w Kosowie lobbując „sprawę kosowską" w Ameryce. Chociaż Kongres nie mówił jednym językiem w tej kwestii, to - co dało się zaobserwować wielokrotnie w następnych latach - wielu jego członków było zwolennikami bardziej aktywnych działań Ameryki na Bałkanach. Starali się oni naciskać na administrację Busha w tej sprawie. Podnosili kwestię Jugosławii, w tym również Kosowa, w swoich wystapieniach w Kongresie USA, który np. w 1989 r. przyją kilka rezolucji, zablokowanych jednak przez Departament Stanu i Biały Dom ${ }^{68}$. Wprawdzie za politykę zagraniczną

${ }^{67}$ Por. np.: Country Reports on Human Rights Practices for 1989. Report Submitted to the Committee on Foreign Affairs House of Representatives and the Committee on Foreign Relations U.S. Senate by the Department of State, Washington 1990, s. 1304-1319; Country Reports on Human Rights Practices for 1990. Report Submitted to the Committee on Foreign Relations U.S. Senate and the Committee on Foreign Affairs House of Representatives by the Department of State, Washington 1991, s. 1342-1359.

${ }^{68}$ J. Glaurdić, op. cit., s. 40; M. Klemenčič, The International Community and the FRY/Belligerents, 1989-1997, [w:] Confronting the Yugoslav Controversies. A Scholars' Initiative, ed. by Ch. Ingrao and T.A. Emmert, 2nd ed., West Lafayette 2013, s. 158. 
odpowiada w Ameryce administracja prezydenta, a kongresmani moga tylko pośrednio wpływać na decyzje władz ${ }^{69}$, to był to wyraźny sygnał zainteresowania części elit politycznych Ameryki problemami wewnętrznymi federacji jugosłowiańskiej. Jedną z rezolucji przyjęła Izba Reprezentantów dzień po uroczystościach 600-lecia bitwy na Kosowym Polu. Amerykańscy kongresmani podkreślili, że USA popieraja niezależność, jedność $i$ integralność terytorialna Jugostawii. Jednak ich zaniepokojenie budziły przypadki łamania praw człowieka w Kosowie. Dlatego wezwali rząd Jugosławii do podjęcia wszystkich niezbędnych kroków, by powstrzymać przemoc i rozlew krwi w tej prowincji. Apelowali również do władz Stanów Zjednoczonych, by monitorowały kwestię praw człowieka w SFRJ ${ }^{70}$. Działania kongresmanów w sprawie Kosowa spotkały się ze sprzeciwem władz jugosłowiańskich ${ }^{71}$.

Narastaniem konfliktu serbsko-albańskiego zaniepokojony był także L. Eagleburger. Jeszcze przed nominacją na zastępcę sekretarza stanu, podczas przesłuchania przed senacką komisja spraw zagranicznych w połowie marca 1989 r., dyplomata ten zauważył, że w Jugosławii - poza problemami ekonomicznymi - pojawił się ponownie niebezpieczny nacjonalizm, a bardzo ważną osobą w tej „grze” był S. Milošević. Zdaniem Eagleburgera, przywódca Serbii używał serbskiego nacjonalizmu

${ }^{69}$ Więcej na ten temat zob.: Ł. Wordliczek, Ksztattowanie się uprawnień prezydenta USA w polityce zagranicznej, Kraków 2003, s. 27-68; R. Bania, Polityka zagraniczna USA $w$ drugiej połowie XX $i$ na poczatku XXI wieku, [w:] Ameryka. Społeczeństwo, kultura, polityka, red. T. Płudowski, t. 3, Polityka i stosunki międzynarodowe, Toruń 2008, s. 205-214.

${ }^{70}$ Section 862 of House Resolution 2655, June 29, 1989, [w:] The Kosovo Conflict. A Diplomatic History Through Documents, eds. P.E. Auerswald and D.P. Auerswald, Cambridge-The Hague 2000, s. 35-36.

${ }^{71}$ Zob. np. J.W. Western, Yugoslavia: Crisis in the Federation, „CRS Report for Congress", 12 VII 1990, no. 90-333 F, s. 25. 
w Kosowie, a także starał się wpływać na decyzje władz federalnych. Amerykański dyplomata stwierdził ponadto, że rozwój zdarzeń w Jugosławii jest bardzo niebezpieczny i chociaż nie można jeszcze powiedzieć, że dojdzie do starć zbrojnych, to jednak sytuacja - w odniesieniu do kwestii nacjonalistycznych - jest najgorsza od czasu zakończenia II wojny światowej ${ }^{72}$.

Administracja Busha, opowiadając się za jednością SFRJ, starała się wspierać tych polityków, którzy pragnęli utrzymania wielonarodowego państwa. Dlatego ważne miejsce w polityce Waszyngtonu zajmował A. Marković. Polityk ten liczył na pomoc Zachodu w procesie przemian w Jugosławii, a szczególną rolę w tych działaniach miały odegrać - według niego - Stany Zjednoczone. Jak stwierdził Robert Rackmales, zastępca W. Zimmermanna w Belgradzie, nasze wysitki w latach 1989-1990 byty próba wsparcia Markovicia, którego postrzegaliśmy jako najlepsza nadzieje, być może ostatniq nadzieje, ponieważ $w$ przypadku jego niepowodzenia perspektywy byty bardzo ponure ${ }^{73}$. Podczas jednej z rozmów Marković

${ }^{72}$ Nomination of Lawrence S. Eagleburger. Hearings before the Committee on Foreign Relations, United States Senate, One Hundred First Congress, First session, March 15 and 16, 1989, Washington 1989, s. 35-36. Warto dodać, że Milošević przez długi czas cieszył się dużą popularnością wśród polityków zachodnich. Niektórzy z nich liczyli, iż stanie się on komunistycznym reformatorem w SFRJ. Niewątpliwie w tworzeniu tego pozytywnego wizerunku pomagały Miloševiciowi dobra znajomość angielskiego a także kontakty, które nawiązał w latach 70. i 80. jako dyrektor banku. Również Amerykanie, w tym ambasador J. Scanlan, jak i L. Eagleburger, uważali Serba za liberalnego reformatora i osobę, która może być alternatywą dla dotychczasowych partyjnych funkcjonariuszy w Jugosławii, zob. L. Sell, Slobodan Milosevic and the Destruction of Yugoslavia, Durham-London 2002, s. 140-141.

${ }^{73}$ Yugoslavia Breaks Up. Robert Rackmales. Deputy Chief of Mission, American Embassy, Belgrade, Yugoslavia, 1989-1993, [w:] American Diplomats. The Foreign Service at Work, ed. by W.D. Morgan and Ch.S. Kennedy, New York 2004, s. 229. 
oświadczył Zimmermannowi, że potrzebuje nie tylko wsparcia politycznego Ameryki, ale także ekonomicznego - określając je na gigantyczną kwotę 4 mld dolarów ${ }^{74}$. Jednak ambasador USA zdawał sobie sprawę, iż Waszyngton nie zgodzi się na taka operację, biorąc pod uwagę priorytety polityki zagranicznej Ameryki, bagaż nacjonalizmu SFRJ i duże ryzyko takiej pomocy. Premier Jugosławii zabiegał także o wyjazd za Atlantyk, licząc na możliwość osobistego przekonania przywódców supermocarstwa o potrzebie wsparcia jego reform. Ostatecznie do takiej wizyty doszło w połowie października 1989 r. Marković spotkał się wówczas m.in. z prezydentem G. Bushem, przedstawicielami Banku Światowego, Międzynarodowego Funduszu Walutowego i biznesu ${ }^{75}$. Jednak za tymi rozmowami, pomimo oczekiwań strony jugosłowiańskiej, nie poszły konkretne rozwiązania, zwłaszcza finansowe. Spotkanie z prezydentem USA trwało około pół godziny. Uczestniczyli w nim także m.in.: sekretarz stanu J. Baker, doradca ds. bezpieczeństwa narodowego B. Scowcroft i przedstawiciel SIV Dževad Mujezinović ${ }^{76}$. W wydanym po tych rozmowach komunikacie poinformowano, że G. Bush potwierdził swoje zdecydowane poparcie dla jugostowianskiej niepodlegtości, jedności i suwerenności, i pozytywnie przyjął zobowiązanie A. Markovicia do przeprowadzenia reform gospodarczych oraz budowania demokratycznego pluralizmu w Jugosławii. Obaj przywódcy omawiali też trudne wyzwania gospodarcze

${ }^{74}$ W. Zimmermann, Origins..., s. 46.

${ }^{75}$ S.L. Woodward, Costly Disinterest: Missed Opportunities for Preventive Diplomacy in Croatia and Bosnia and Herzegovina, 1985-1991, [w:] Opportunities Missed, Opportunities Seized. Preventive Diplomacy in the Post-Cold War World, ed. by B.W. Jentleson, Lanham 2000, s. 143-144.

${ }^{76}$ Został on ambasadorem SFRJ w USA w listopadzie 1989 r., Serbia's Diplomatic Representatives to the U.S., http://www.serbiaembusa.org/us. php (dostęp 11 II 2013). 
i polityczne, przed którymi stała SFRJ, jak również możliwości wsparcia programu reform, niezbędne do przyciagnięcia zagranicznych inwestycji i ożywienia gospodarczego Jugosławii ${ }^{77}$. Marković poinformował po rozmowach, że ponowił zaproszenie dla przywódcy USA, aby odwiedził Jugosławię, a także podkreślił, że pragnie przebudować gospodarkę SFRJ, a do tego szczególnie istotne będą amerykańskie banki, przedsiębiorstwa i technologie ${ }^{78}$. Pozornie wizyta w Ameryce mogła wydawać się sukcesem, gdyż doszło do spotkania z najważniejszymi osobami w USA i, według relacji R. Rackmalesa, jugosłowiański polityk zrobit dobre wrażenie. Byt dynamiczna osobq $i$ wiedziat, jak rozmawiać z przedstawicielami Zacho$d u^{79}$. Jednak, jak przyznaje w swoich wspomnieniach W. Zimmermann, A. Marković przekonał się na własne oczy, iż Jugosławia nie jest w centrum waszyngtońskiego wszechświata, a podczas krótkiej rozmowy z prezydentem Stanów Zjednoczonych stronę amerykańską bardziej interesowała tematyka sytuacji w ZSRR i opinie o M. Gorbaczowie, niż problemy Jugosławii ${ }^{80}$. Jak zauważył jeden z ówczesnych przedstawicieli administracji, Robert L. Hutchings, spoglądając z perspektywy czasu my $i$ nasi europejscy partnerzy powinniśmy poświęcić więcej uwagi wysitkom Markovicia, by wykuć nowy jugostowianski konsensus $w$ kwestii ekonomicznych i politycznych reform. [...] jego wizyta byta jak odgtos klaskania jedna

${ }^{77}$ Statement by Press Secretary Fitzwater on the President's Meeting With Prime Minister Ante Markovic of Yugoslavia, October 13, 1989, American Presidency Project: George Bush, http://www.presidency.ucsb.edu/ (dostęp 20 X 2013).

${ }^{78}$ Bush Meets with Yugoslav Prime Minister, 13 X 1989, http://www. apnewsarchive.com/1989/Bush-Meets-With-Yugoslav-Prime-Minister/id-827481841e71c573f509016b542a5306 (dostęp 11 X 2013).

${ }^{79}$ Yugoslavia Breaks Up..., s. 229.

${ }^{80}$ W. Zimmermann, Origins..., s. 47. 
ręka: otrzymat uprzejme wystuchanie $i$ stowa otuchy, zamiast konkretnego wsparcia ekonomicznego i politycznego ${ }^{81}$. Premier Jugosławii przekonał się również osobiście o zainteresowaniu przedstawicieli Kongresu kwestią Kosowa, gdy podczas spotkania z kongresmanami niektórzy z nich atakowali jego rząd za postawę serbskich władz w tej prowincji ${ }^{82}$. Amerykanie nie wykorzystali więc szansy, aby faktycznie pomóc politykowi, który starał się powstrzymać narastający kryzys w SFRJ. Dla Waszyngtonu wówczas ważniejszą była jednak, na gruncie europejskim, np. kwestia niemiecka czy pomoc Polsce (premier Tadeusz Mazowiecki wystapił o pomoc ekonomiczną i ją otrzymał $)^{83}$. Takiej dobrej woli wobec Jugosławii zabrakło. Na inny ważny czynnik zwraca uwagę W. Zimmermann, który podkreślił, że A. Marković miał znacznie większe problemy niż np. przywódcy Węgier, Czechosłowacji i Polski, otrzymujący wsparcie USA. Premier SFRJ nie posiadał bowiem silnej władzy w kraju, w którym ważniejszą rolę odgrywały republiki. Dlatego m.in. nie był w stanie powstrzymać działań S. Miloševicia w Kosowie. Wielu współpracowników Zimmermanna z ambasady USA w Belgradzie jeszcze w 1989 r. uważało, że Marković nie ma szans osiagać sukcesu i walczy w przegranej bitwie ${ }^{84}$.

Chociaż ambasador Ameryki nie zgadzał się wtedy z tymi opiniami, to jednak faktycznie próba ratowania kraju przez

${ }^{81}$ R.L. Hutchings, op. cit., s. 304.

${ }^{82}$ W. Zimmermann, Origins..., s. 47.

${ }^{83}$ J. Glaurdić, op. cit., s. 67. Więcej o relacjach Stanów Zjednoczonych z Polską w tym okresie zob. np.: R. Kuźniar, Droga do wolności. Polityka zagraniczna III Rzeczypospolitej, Warszawa 2008, s. 93-94; Ku zwycięstwu „Solidarności”. Korespondencja Ambasady USA w Warszawie z Departamentem Stanu. Styczeń-wrzesień 1989, przedm. J.R. Davis Jr., wstęp i wybór G.F. Domber, oprac. G.F. Domber [et al.], Warszawa 2006.

${ }^{84}$ Interview with Warren Zimmermann... 
szefa rządu federalnego zakończyła się porażką. Także Susan Woodward potwierdza, że Amerykanie w 1989 r. nie do końca wierzyli w szanse powodzenia Markovicia. Według niej, władze USA dawały przewodniczącemu SIV 50\% szans na osiagnięcie sukcesu $^{85}$. Natomiast przedstawiciel Departamentu Stanu, Robert L. Barry, zauważa, iż chociaż Ameryka mocno wspierała Markovicia, myśląc, że ma zdolność utrzymania kraju razem, to jednak nie posiadał on właściwej bazy politycznej i zaniedbał wyrobienie sobie platformy politycznego poparcia ${ }^{86}$. Faktycznie, polityk ten funkcjonował przez długi czas bez wsparcia silnej struktury politycznej, zwłaszcza po rozpadzie jugosłowiańskiej partii komunistycznej. Utworzone przez niego w lipcu $1990 \mathrm{r}$. własne ugrupowanie - Sojusz Sił Reformatorskich Jugosławii (Savez reformskih snaga Jugoslavije, SRSJ), w wyborach republikańskich, które odbyły się w drugiej połowie 1990 r., nie odegrało większej roli na scenie politycznej ${ }^{87}$.

Administracja Busha ograniczała się głównie do werbalnego popierania wysiłków jugosłowiańskiego polityka (np. do rozmów telefonicznych i listów przywódcy supermocarstwa). Jak przyznaje R. Rackmales, w związku z pogarszaniem się sytuacji w SFRJ, Stany Zjednoczone nie planowały realnej pomocy, co powodowało frustrację Markovicia pytajacego, ile jest warte wsparcie Ameryki bez konkretnych pieniędzy?88 Przewodniczacy

${ }^{85}$ S.L. Woodward, Costly Disinterest..., s. 144.

${ }^{86}$ Interview with Robert L. Barry, Interviewed by: Charles Stuart Kennedy, Initial Interview date: October 2, 1996, http://www.loc.gov (dostęp 2 XI 2014).

${ }^{87}$ S.L. Woodward, Balkan Tragedy. Chaos and Dissolution after the Cold War, Washington 1995, s. 129; M. Pejanović, Through Bosnian Eyes. The Political Memoir of the Bosnian Serb, introd. by R.J. Donia, trans. by M. Bowder, West Lafayette 2004, s. 3 i nast.

${ }^{88}$ Interview with Robert Rackmales, Interviewed by: Charles Stuart Kennedy, Initial interview date: May 11, 1995, http://www.loc.gov/ (dostęp $1 \mathrm{XI} 2014)$. 
SIV, bez rzeczywistej pomocy Zachodu, musiał samodzielnie walczyć z problemami politycznymi, ekonomicznymi, społecznymi i narodowościowymi Jugosławii.

Po przybyciu do Belgradu, zgodnie z sugestiami L. Eagleburgera, W. Zimmermann nawiązał kontakty z przedstawicielami władz republikańskich, zdając sobie sprawę, iż to one są realną siłą w SFRJ. Z nowym ambasadorem USA spotkali się przewodniczący prezydiów wszystkich republik, poza jedną - Serbią. Milošević uzasadniał swoją odmowę tym, iż za bilateralne stosunki odpowiadał federalny sekretariat spraw zagranicznych, a on sam był zbyt zajęty, aby przyjmować ambasadorów ${ }^{89}$. Niewątpliwie na tę niechęć serbskiego przywódcy mogła wpływać zdecydowana postawa przedstawiciela Ameryki wobec wydarzeń w Kosowie. Dodatkowo Zimmermann „podpadł” Miloševiciowi, nie przybywajacc, podobnie jak wielu innych dyplomatów z państw zachodnich, na wspominane wcześniej uroczystości na Kosowym Polu w czerwcu 1989 r. Przewodniczacy partii komunistycznej i Prezydium Serbii uznał Amerykanina za sprawcę tego „zachodniego bojkotu” i człowieka o nastawieniu antyserbskim, dlatego też odmawiał spotkania z nim aż do stycznia $1990 \mathrm{r} .{ }^{90}$

W grudniu 1989 r. Zimmermann raportował do Waszyngtonu, że w wyniku sporu słoweńsko-serbskiego struktura

${ }^{89}$ W. Zimmermann, Origins..., s. 18. Zimmermann podkreślił w trakcie jednego wywiadu, iż w owym czasie w większości raportów i opracowań administracji amerykańskiej Milošević był kluczowa postacia, a jego polityka budziła duże zaniepokojenie władz USA, Interview with Warren Zimmermann...

${ }^{90}$ W. Zimmermann, Origins..., s. 20; L.J. Cohen, Serpent in the Bosom. The Rise and Fall of Slobodan Milošević, revised ed., Boulder 2002, s. 188; R. Holbrooke, To End a War, New York 1998, s. 26. W okresie późniejszym, podczas rozmów z zachodnimi dyplomatami Milošević przyznał, że był to jeden z jego wielkich błędów, L. Sell, op. cit., s. 143. 
etnicznej tolerancji, która nigdy nie byta bardzo silna w Jugostawii, została mocno rozdarta, polityka Miloševicia szkodzi jedności SFRJ, a w Słowenii coraz więcej osób myśli o secesji. Konkludując, amerykański ambasador ostrzegał, że wkrótce może dojść do sytuacji, gdy taktyka Miloševicia dzielenia może pobudzić stoweński separatyzm $i$ chorwacki nacjonalizm, $i$ ostatecznie podzielić kraj ${ }^{91}$.

Dla administracji G. Busha najważniejszym celem w polityce wobec SFRJ było zachowanie jedności tego państwa. Podczas spotkania w Brukseli w połowie grudnia 1989 r. przedstawicieli Departamentu Stanu z ambasadorami USA, pracujaccymi w Europie, omawiano wiele kluczowych wówczas dla kontynentu spraw, szczególnie problem zjednoczenia Niemiec. W kwestii Jugosławii podkreślono potrzebę utrzymania jej jedności, nawet w formie luźnej federacji republik. Chociaż $\mathrm{w}$ tej naradzie nie uczestniczył szef Departamentu Stanu, to zdaniem Thomasa Patricka Melady'ego, przekaz jego zastępcy, L. Eagleburgera, do dyplomatów amerykańskich był jasny: zachowanie SFRJ, a w przypadku jej rozpadu będzie to model dla dezintegracji ZSRR ${ }^{92}$.

Pewien wpływ na odbiór problemów Jugosławii w administracji G. Busha miała niewatpliwie osobista wyprawa Eagleburgera do tego kraju 25-26 lutego 1990 r. Waszyngton zdecydował się skierować zastępcę sekretarza stanu, by ocenił sytuację na miejscu. Dyplomata ten podczas swego dwudniowego pobytu spotkał się z przedstawicielami władz, jak i opozycji. Jego rozmówcami byli m.in.: A. Marković, S. Milošević, szef dyplomacji Jugosławii - Budimir Lončar i przewodniczący Prezydium Słowenii - Janez Stanovnik. Eagleburger powiedział wówczas prasie, że jest pod wrażeniem programu reform Markovicia,

${ }^{91}$ W. Zimmermann, Origins..., s. 53.

92 T.P. Melady, op. cit., s. 138; W. Zimmermann, Origins..., s. 41-42. 
zaznaczając równocześnie, iż kwestie polityczne SFRJ byłoby łatwiej rozwiązać, gdyby jej gospodarka była zdrowsza. Podkreślił także radość z powodu wprowadzanego pluralizmu politycznego, jak i poparcie Stanów Zjednoczonych dla rządu federalnego. Wyraził jednocześnie zaniepokojenie z powodu łamania praw człowieka w Kosowie ${ }^{93}$. Eagleburger w czasie spotkania z przedstawicielem Słowenii - J. Stanovnikiem - usłyszał ostrzeżenie, iż po wyborach nowe władze tej republiki mogą dążyć do secesji, co groziło libanizacja94. Natomiast podczas rozmowy ze S. Miloševiciem ${ }^{95}$ Eagleburger poruszył m.in. kwestię wsparcia reform A. Markovicia, problem łamania praw człowieka i sytuację w Kosowie. Przedstawiciel administracji Busha ostrzegał, iż twarda polityka Serbii w tej prowincji może doprowadzić do pogorszenia stosunków Jugosławii z USA. Milošević odpowiedział, iż Serbowie bronia się tylko przed islamskimi fundamentalistami i narko-mafia z Kosowa, a Albańczycy dopuszczaja się systematycznych morderstw i gwattów na serbskich kobietach i dzieciach. Tę albańska strategie - zdaniem Miloševicia - wspieraja Stoweńcy, którzy chca wykorzystać kwestię Kosowa do destabilizacji Serbii ${ }^{96}$.

93 J. Glaurdić, op. cit., s. 80; W. Zimmermann, Origins..., s. 58.

${ }^{94}$ W. Zimmermann, Origins..., s. 58. Stanovnik pod koniec 1988 r. przebywał z nieoficjalną wizytą w USA, podczas której występował publicznie, spotykał się z różnymi politykami amerykańskimi. Przedstawił wówczas ponury obraz sytuacji w federacji i powiedział, że istnieje niebezpieczeństwo wojny domowej w Jugosławii. Oświadczenia Stanovnika zostały powtórzone przez media w SFRJ i wywołały polityczną burzę, co dodatkowo zaogniło napięte już relacje słoweńsko-serbskie, R. Dizdarević, op. cit., s. 283-285; Z.T. Irwin, Yugoslavia's Foreign Policy and Southeastern Europe, [w:] Problems of Balkan Security. Southeastern Europe in the 1990s, ed. P.S. Shoup, Washington 1990, s. 166-167.

${ }^{95}$ Eagleburger poznał osobiście Miloševicia podczas swej pracy w SFRJ jako ambasador USA.

${ }^{96}$ W. Zimmermann, Origins..., s. 58-60. 
Kolejnym sygnałem o złej sytuacji w SFRJ było spotkanie Eagleburgera, podczas jego wizyty w Belgradzie, z kilkunastoma przedstawicielami opozycji i obrońców praw człowieka z każdej republiki i z Kosowa. O ile część rozmówców popierała Markovicia oraz jedność Jugosławii, o tyle reprezentanci Chorwacji i Słowenii mówili o tym, iż Jugosławia nie musi istnieć jako całość za wszelką cenę, że możliwe jest dążenie Lublany do secesji. Na koniec tego spotkania słoweński polityk, Peter Jambrek, zapytał Eagleburgera o to, co zrobia Stany Zjednoczone, jeśli Słoweńcy wyjda z SFRJ. Amerykański dyplomata, zaskoczony tym pytaniem, odpowiedział, że USA mają nadzieję, iż Słowenia tego nie uczyni i że nie mogą nic zrobić, by zmienić politykę władz słoweńskich ${ }^{97}$. Słowa te były później różnie interpretowane przez polityków i obserwatorów wydarzeń w Jugosławii. Dla części Słoweńców oznaczały bowiem „zielone światło” dla ich działań secesjonistycznych ${ }^{98}$.

Po tym spotkaniu Eagleburger powiedział pracownikom ambasady, że nie widzi możliwości, by przedstawiciele narodów Jugosławii utrzymali swój kraj w jedności ${ }^{99}$. Trzeba także pamiętać, że do wizyty reprezentanta Ameryki doszło w ważnym dla SFRJ momencie - po rozpadzie partii komunistycznej, jak również w trakcie przygotowań do pierwszych po II wojnie światowej demokratycznych wyborów republikańskich (na początek w Słowenii i Chorwacji). Osoby, które liczyły, iż przyjazd Eagleburgera przyniesie zdecydowane poparcie procesu demokratyzacji w Słowenii i Chorwacji oraz konkretną pomoc ekonomiczną dla rządu A. Markovicia,

${ }^{97}$ D. Halberstam, op. cit., s. 29.

${ }^{98}$ Por.: ibidem; W. Zimmermann, Origins..., s. 62.

${ }^{99}$ Interview with Ruth E. Hansen, Interviewed by Charles Stuart Kennedy, Initial interview date: June 21, 2004, http://www.loc.gov/ (dostęp 11 I 2015). 
były zawiedzone ${ }^{100}$. Natomiast zastępca sekretarza stanu wyjeżdżał z Jugosławii niewątpliwie zaniepokojony, gdyż potwierdziły się jego wcześniejsze obawy o niebezpieczeństwie wiszacym nad narodami SFRJ. I chociaż oświadczył, że Jugosłowianie wiedza dobrze, co może się stać z nimi, jeśli się podziela ${ }^{101}$, to wizyta w kraju, w którym spędził jako dyplomata kilka lat, była dla niego niewatpliwie dużym szokiem. Po powrocie do Waszyngtonu powiedział swoim współpracownikom, że o ile wcześniej mówiono mu o złej sytuacji w państwie jugosłowiańskim, to jest znacznie gorzej niż ktokolwiek myślat. To będzie o wiele bardziej krwawe niż myśleliśmy ${ }^{102}$.

W wyniku misji Eagleburgera w Belgradzie dyplomacja Stanów Zjednoczonych podjęła pewne działania w sprawie Jugosławii - zostały wysłane instrukcje do ambasad USA w Europie Zachodniej i Wschodniej, w których wzywano do poruszenia kwestii państwa jugosłowiańskiego, w tym poparcia jedności i demokracji oraz reform A. Markovicia w tej wielonarodowej federacji. Amerykańscy dyplomaci mieli również przekonywać władze krajów europejskich, iż rozpad SFRJ nie jest ani w interesie narodów Jugosławii, ani bezpieczeństwa Europy ${ }^{103}$.

Niestety, działania te nie przyniosły efektów, a wkrótce nowym problemem stały się wybory w Słowenii i Chorwacji (odbyły się w kwietniu i maju 1990 r.). W słoweńskiej republice zwyciężyła koalicja Demokratyczna Opozycja Słowenii (Demokratska opozicija Slovenije, Demos), której przywódcą był Lojze Peterle ${ }^{104}$. Jednak $\mathrm{w}$ równocześnie przeprowadzonych wyborach prezydenckich zwyciężył M. Kučan, reprezentujący

${ }^{100}$ J. Glaurdić, op. cit., s. 80.

${ }^{101}$ L.J. Cohen, Broken Bonds. Yugoslavia's Disintegration and Balkan Politics in Transition, Boulder-San Francisco-Oxford 1995, s. 218.

${ }^{102}$ D. Halberstam, op. cit., s. 29.

${ }^{103}$ W. Zimmermann, Origins..., s. 64-65.

${ }^{104}$ Został on premierem rządu Słowenii. 
blok postkomunistyczny ${ }^{105}$. Nowe władze republiki chciały przekształcić SFRJ w luźniejszą konfederację lub dążyć do suwerenności. W lipcu 1990 r. parlament słoweński przyją Deklaracje suwerenności państwowej Republiki Stowenii, która nie oznaczała jednak automatycznie jej wystapienia z federacji jugosłowiańskiej. Jak stwierdził L. Peterle: $W$ tych sprawach, w których prawa federacji będa dla nas do przyjęcia, będziemy je szanować [...]. Naszym hastem nie jest niepodlegtość, lecz suwerenność. Akceptujemy Jugostawię jako konfederację, jeśli Stowenia ma $w$ jej ramach petna suwerenność. $W$ przeciwnym razie alternatywa będzie słoweńska niepodlegtośćc ${ }^{106}$.

Po wyborach w Słowenii do urn wyborczych poszli również obywatele Chorwacji. Tu zwycięzcą okazała się Chorwacka Wspólnota Demokratyczna (HDZ), na czele której stał Franjo Tuđman. Został on wybrany przez parlament (Sabor) prezydentem Chorwacji ${ }^{107}$. Stał się w ten sposób pierwszym niekomunistycznym przywódca republiki jugosłowiańskiej. Wkrótce jego najbliższy współpracownik z HDZ, Stipe Mesić staną na czele chorwackiego rządu.

Wybory w Słowenii i Chorwacji miały być elementem stabilizacji i demokratyzacji w państwie, jednak de facto przyczyniły się do dalszych napięć w Jugosławii. Równocześnie coraz silniej można było zaobserwować wykorzystywanie w bieżącej

${ }^{105}$ Więcej zob.: K. Krysieniel, J. Wojnicki, Partie $i$ systemy partyjne państw byłej Jugostawii (Bośnia i Hercegowina, Chorwacja, Czarnogóra, Macedonia, Serbia, Stowenia), Pułtusk-Warszawa 2009, s. 180-181; E. Bujwid-Kurek, Państwa pojugosłowiańskie. Szkice politologiczne, Kraków 2008, s. 44-46, 72 i nast.

${ }^{106}$ Cyt. za: M.J. Zacharias, Komunizm..., s. 484.

${ }^{107}$ Więcej zob.: K. Krysieniel, System polityczny Republiki Chorwacji, Poznań-Chorzów 2007, s. 69-76; K. Składowski, System rzqdów w Republice Chorwacji, Łódź 2013, s. 53. 
polityce odwołań do przeszłości, szczególnie tej związanej z trudnymi relacjami serbsko-chorwackimi, zwłaszcza z okresu II wojny światowej ${ }^{108}$. W miarę upływu czasu narastał problem relacji władz w Zagrzebiu z ludnością serbska, zamieszkującą Chorwację, co związane było z polityką przywódców chorwackich i serbskich, jak również obawami samych Serbów chorwackich, podsycanymi przez S. Miloševicia ${ }^{109}$.

Amerykanie ambiwalentnie podchodzili do wyborów republikańskich w 1990 r. w SFRJ. Z jednej strony był to bowiem proces demokratyczny. Jednak Waszyngton niepokoiła postawa i programy części nowych ugrupowań politycznych, gdyż do władzy mogli dojść zwolennicy konfederacji, czy nawet rozpadu państwa. Dlatego dyplomacja amerykańska uważała, iż proces wyborczy w republikach może być niebezpieczny i przyniesie więcej szkód, niż korzyści. W początkowym okresie administracja G. Busha traktowała np. przywódców chorwackich jako agresywnych nacjonalistów, nieczułych na żądania serbskiej mniejszości w Chorwacji. Oskarżała nowe władze w Zagrzebiu o próbę zniszczenia Jugosławii, bez względu na konsekwencje tych działań ${ }^{110}$. Obawiała się

${ }^{108}$ Więcej zob. np.: M. Rekść, Mit II wojny światowej w polityce historycznej serbskich $i$ chorwackich nacjonalistów, [w:] Mity historyczno-polityczne, wyobrażenia zbiorowe, polityka historyczna. Studia i materiaty, t. 2, pod red. E. Ponczka, A. Sepkowskiego, Toruń 2012, s. 211-231; eadem, Mity narodowe $i$ ich rola $w$ kreowaniu polityki na przykładzie państw bytej Jugosławii, Łódź 2013, s. 264 i nast.; S.P. Ramet, op. cit., s. 349, 368-369.

${ }^{109}$ M.J. Zacharias, Komunizm..., s. 485; N. Barić, Main Characteristics of the self-proclaimed Republic of Serb Krajina, 1990-1991-1995 on Croatian territory, [w:] Asymetryczne Batkany. Działania asymetryczne, militarne i polityka. Materiaty i studia, pod red. nauk. D. Gibas-Krzak, Częstochowa 2015, s. 131.

${ }^{110}$ J.-F. Morel, American-Croatian Relations during the 1990s, [w:] Croatia since Independence. War, Politics, Society, Foreign Relations, ed. by S.P. Ramet, K. Clewing, R. Lukic, München 2008, s. 353. 
polityki F. Tuđmana i jego HDZ, która mogła zaognić relacje serbsko-chorwackie (i tak się stało) ${ }^{111}$. Przedstawiciele Ameryki z niepokojem więc obserwowali popularność partii nacjonalistycznych i ich zwycięstwa, chociaż przebiegały one zgodnie z demokratycznymi normami. Jednak zagrożony był najważniejszy priorytet polityki USA wobec SFRJ - utrzymanie jednolitego państwa. Dlatego przedstawiciel administracji Busha, David Gompert, pisał, iż Waszyngton traktował nowych przywódców republikańskich jako separatystów i przyjmował ich deklaracje o prawie do bycia wolna, demokratyczną częścia Zachodu jako cynizm. Równocześnie, jak dodaje amerykański dyplomata, niezależnie od opinii o słoweńskich i chorwackich liderach, władze USA wierzyły, iż to S. Milošević jest główną siłą napędową kierująca Jugosławię w stronę gwałtownego końca ${ }^{112}$.

Ambasador Zimmermann zdawał sobie sprawę, iż republikańskie wybory 1990 r. moga przyczynić się do narodzin demokracji, ale także $i$ do uduszenia jej $w$ kotysce. Ostatecznie okazały się obosiecznym mieczem, gdyż USA popierały je, licząc na demokratyczne zmiany, jednak faktycznie doprowadziły do władzy nietolerancyjnych przywódców i spolaryzowały nacjonalizm ${ }^{113}$.

Wkrótce sytuacja zaczęła się zaogniać w Chorwacji, w której armia federalna opróżniła magazyny z uzbrojeniem dla tamtejszej Obrony Terytorialnej (TO), zaś miejscowi Serbowie, wspierani przez S. Miloševicia, rozpoczęli tworzenie

${ }^{111}$ Zob. W. Zimmermann, Origins..., s. 71-77.

${ }^{112}$ D.C. Gompert, The United States and Yugoslavia's Wars, [w:] The World and Yugoslavia's Wars, ed. by R.H. Ullman, New York 1996, s. 124.

${ }^{113}$ W. Zimmermann, Origins..., s. 65; S.L. Woodward, International Aspects of the Wars in Former Yugoslavia, [w:] Burn This House: The Making and Unmaking of Yugoslavia, ed. J. Udovički, J. Ridgeway, DurhamLondon 2000, s. 219. 
własnych autonomicznych struktur, niezależnych od władz w Zagrzebiu. W niektórych częściach republiki, np. w Krajinie, dochodziło do blokad dróg (tzw. rewolucja pni), a wkrótce także do starć114.

Administracja G. Busha otrzymywała sygnały o coraz bardziej napiętej sytuacji z wielu źródeł. Przywódcy Ameryki nie mogli więc później twierdzić, że byli zaskoczeni rozwojem wydarzeń w SFRJ i że nie wiedzieli o narastającym niebezpieczeństwie dezintegracji tego państwa. Wielokrotnie o napięciach w Jugosławii informowały służby wywiadowcze supermocarstwa, w tym CIA ${ }^{115}$. Przykładowo, w jej raportach z sierpnia i września 1990 r. donoszono, że ryzyko wybuchu walk w Chorwacji, a także ich „rozlania się” na wieloetniczną Bośnię i przerodzenia się w wojnę domowa, jest bardzo duże, że kryzys ten może grozić przekształceniem się Bałkanów w główny region niestabilności pogranicza Europy ${ }^{116}$.

Jednak najbardziej znany publicznie raport $\mathrm{w}$ tej sprawie powstał w październiku 1990 r., a został ujawniony przez

${ }^{114}$ Więcej zob. np.: M.A. Hoare, Wojna jugostowiańska, [w:] Polityka Europy Środkowej i Poludniowo-Wschodniej po 1989 roku, pod red. S.P. Ramet, przeł. M. Gałaska [et al.], Warszawa 2012, s. 145; P. Żurek, Oblężenie Dubrownika (1991-1992), [w:] Bałkany Zachodnie między przesztościa a przyszłościq, pod red. P. Chmielewskiego i S.L. Szczesio, Łódź 2013, s. 131-133; Z. Radelić [et al.], Stvaranje hrvatske države i Domovinski rat, Zagreb 2006, passim.

${ }^{115} \mathrm{O}$ niebezpieczeństwie wybuchu wojny domowej i działań podjętych przez armię federalna przeciwko Słowenii i Chorwacji informowała CIA np. w 1988 r., M. Łakota, Wizerunek Chorwacji w stosunkach międzynarodowych, [w:] Wybrane problemy wspótczesnych stosunków międzynarodowych, pod red. M.S. Wolańskiego, Wrocław 2008, s. 177.

${ }^{116}$ Yugoslavia: Civil Conflict Likely in Croatia, 18 VIII 1990, http:// www.foia.cia.gov (dostęp 12 X 2013); Yugoslavia: End of a Nation-Building Experiment, 21 IX 1990, http://www.foia.cia.gov (dostęp 12 X 2013); J. Glaurdić, op. cit., s. 97-99. 
„The New York Times” miesiąc później ${ }^{117}$. Często w literaturze przedmiotu jest on przedstawiany jako ostrzeżenie CIA, jednak de facto był to dokument (national intelligence estimates, NIE) przygotowany przez organ koordynujący działania służb wywiadowczych USA (w tym m.in. CIA), jakim jest Narodowa Rada Wywiadu (National Intelligence Council, NIC). W jego przygotowaniu uczestniczyła grupa ekspertów, którym przewodził doświadczony dyplomata i analityk Marten van Heuven ${ }^{118}$. W raporcie tym ostrzegano o niebezpieczeństwie rozpadu SFRJ w ciagu dwóch lat. Sugerowano, że reformy ekonomiczne moga nie powstrzymać upadku państwa, co zakończy się wojną domowa. Niestety, dokument ten nie wpłyną na politykę Waszyngtonu. Według M. van Heuvena, nikt nie był zadowolony z tej proroczej oceny i chociaż była ona powszechnie znana, to ostatecznie została zignorowana, również przez osoby majace doświadczenie w sprawach jugosłowiańskich, jak T. Niles, L. Eagleburger czy B. Scowcroft ${ }^{119}$.

Większość dyplomatów i polityków amerykańskich uznała to ostrzeżenie ze strony służb wywiadowczych za przesadzone. Doradca prezydenta ds. bezpieczeństwa B. Scowcroft nie zgadzał się z tym raportem, uważając, iż jeśli Jugosławia

${ }^{117}$ Yugoslavia Transformed, 18 October 1990, NIE 15-90, [w:] Yugoslavia. From "National Communism" to National Collapse. US Intelligence Community Estimative Products on Yugoslavia, 1948-1990, Pittsburgh 2006, s. 653-674; D. Binder, Evolution in Europe, Yugoslavia Seen Breaking Up Soon, „The New York Times”, 27 XI 1990, s. 7.

${ }^{118}$ Więcej zob.: Interview with Marten Van Heuven, Interviewed by: Charles Stuart Kennedy, Initial interview date: January 31, 2003, http:// www.loc.gov (dostęp 1 XI 2014); T.W. Shreeve, The Intelligence Community Case Method Program: A National Intelligence Estimate on Yugoslavia, [w:] Intelligence and the National Security Strategist: Enduring Issues and Challenges, ed. by R.Z. George, R.D. Kline, Lanham 2006, s. 327-340.

${ }^{119}$ N. Both, From Indifference to Entrapment. The Netherlands and the Yugoslav Crisis 1990-1995, Amsterdam 2000, s. 71. 
przetrwała trudny okres „zimnej wojny”, jak i lata po śmierci Broz-Tity, to będzie trwać dalej ${ }^{120}$. Waszyngton niezmiennie podkreślał poparcie dla rządu Markovicia i jedności Jugosławii (tak samo jak i ZSRR), chłodno podchodząc do prób przedstawicieli Słowenii i Chorwacji uzyskania pomocy USA dla ich działań. Widać to było chociażby w czasie wizyty delegacji chorwackiej w Waszyngtonie jesienią 1990 r. ${ }^{121}$ Chorwaci zdawali sobie sprawę, że w obliczu ewentualnej interwencji zbrojnej wojsk jugosłowiańskich, dyplomacja i presja administracji G. Busha na Serbię i armię federalną - to jedyna szansa na uniknięcie katastrofy ${ }^{122}$.

Rozpatrując kwestię polityki Stanów Zjednoczonych wobec SFRJ musimy także pamiętać o zaangażowaniu w tamtym okresie Amerykanów na Bliskim Wschodzie - to czas opisywanego wcześniej tworzenia koalicji międzynarodowej przeciw Irakowi. Tamten teatr działań był zdecydowanym priorytetem Białego Domu i Departamentu Stanu. Dlatego Waszyngton nie chciał angażować się w jugosłowiańska „beczkę prochu”. Starał się jednak ponownie zachęcić państwa europejskie do zajęcia się kwestią SFRJ. Ale gdy pod koniec 1990 r. amerykańscy dyplomaci podjęli próbę zainteresowania tym zagadnieniem sojuszników na forum NATO, wówczas Francja, według relacji D. Gomperta, zarzuciła Stanom

${ }^{120}$ B. Sparrow, The Strategist: Brent Scowcroft and the Call of National Security, New York 2015, s. 451.

${ }^{121}$ Więcej o tej wizycie zob.: L.J. Cohen, Broken..., s. 219; S. Letica, The West Side Story of the Collapse of Yugoslavia and the Wars in Slovenia, Croatia, and Bosnia-Herzegovina, [w:] This Time We Knew. Western Responses to Genocide in Bosnia, ed. T. Cushman, S.G. Meštrović, New York 1996, s. 182-185; A. Bing, KISS: Keep It Simple, Stupid! Critical Observations of the Croatian American Intellectuals During the Establishment of Political Relations Between Croatia and the United States, 1990-1992, „Review of Croatian History" [Zagreb] 2006, vol. 2, no. 1, s. 181-182.

${ }^{122}$ S. Letica, op. cit., s. 182-183. 
Zjednoczonym „dramatyzowanie” problemu ${ }^{123}$. Zachód nie był wówczas zainteresowany problemem bałkańskim, jak trafnie zauważył M.J. Zacharias, mocarstwa zachodnie [...], z USA na czele, nie miaty na Pótwyspie Batkańskim żadnych żywotnych interesów - politycznych, gospodarczych czy strategicznych. Dotyczyto to zwłaszcza Ameryki, dla której Batkany, jak $i$ sama Jugostawia nie posiadały znaczenia porównywalnego z waga Iraku oraz Kuwejtu ${ }^{124}$.

Do końca 1990 r. we wszystkich republikach SFRJ przeprowadzono wybory, w których w większości zwyciężały ugrupowania opozycyjne lub postkomunistyczne, opowiadające się za nacjonalistycznymi hasłami, a czasami nawet dążące do secesji. Było tak m.in. dlatego, jak zauważył W. Zimmermann, ponieważ zabrakło jugostowiańskich Havlów lub Watęsów, politycznych liderów zdolnych pozyskać ich obywateli za wielkimi demokratycznymi ideami $i^{125}$.

Głosowania potwierdziły wolę dążenia do suwerenności w Słowenii i Chorwacji. Ostatecznie w kraju powstał nowy układ polityczny, w którym władze republikańskie pochodziły z pluralistycznego systemu wyborczego, natomiast federalne z monopartyjnego. Wybory pokazały także słabość tych partii, które były za jednością państwa, a więc chociażby SRSJ - formacji politycznej premiera Markovicia, popieranego werbalnie przez USA. Siły polityczne w poszczególnych

${ }^{123}$ D.C. Gompert, How to Defeat Serbia, „Foreign Affairs” 1994, vol. 73, no. 4, s. 35; idem, The United States..., s. 127. Natomiast R.L. Hutchings, pracujaccy wówczas $\mathrm{w}$ administracji Busha, zauważa, że oprócz postawy Francji, wpływ na brak reakcji, w tamtym okresie, ze strony społeczności międzynarodowej miało oczekiwanie na wynik wyborów w Serbii w grudniu 1990 r. i kwestia iracka. Amerykanin stwierdza, że władze USA niechętnie zgodzity się czekać. To byt bład, R.L. Hutchings, op. cit., s. 307.

${ }^{124}$ M.J. Zacharias, Międzynarodowe uwarunkowania..., s. 154-155.

${ }^{125}$ W. Zimmermann, Origins..., s. 68. 
republikach uzyskały legitymizację swoich dążeń i haseł, co prowadziło do wzrostu napięć w federacji. Ruchom odśrodkowym sprzyjał także niekorzystny stan gospodarki Jugosławii i coraz słabsza pozycja władz centralnych. Wiosna 1991 r. politycy jugosłowiańscy podejmowali kolejne próby powstrzymania rozpadu państwa - niestety bezskutecznie. Co ciekawe, tarcia pomiędzy Belgradem i Zagrzebiem nie przeszkadzały w marcu i kwietniu $1991 \mathrm{r}$. w rozwijaniu przez przywódców Serbii i Chorwacji planów ewentualnej współpracy, mającej zmierzać do podziału Bośni i Hercegowiny ${ }^{126}$. Będzie to jeden z czynników, mających wpływ na politykę Ameryki i jej niechęć do Chorwatów i Serbów.

Ostatnią próbę powstrzymania rozpadu SFRJ podjęli przywódcy Bośni i Hercegowiny oraz Macedonii. Oto Alija Izetbegović i Kiro Gligorov zaproponowali na początku czerwca 1991 r. przekształcenie kraju w „federację państw”"127. Idea ta ostatecznie została odrzucona. Stało się jasne, że wkrótce dojdzie do rozpadu państwa. Nad federacja jugosłowiańska zbierały się ciemne chmury...

W pierwszej połowie $1991 \mathrm{r}$. Amerykanie kontynuowali swoją politykę izolacji od kryzysu na Bałkanach, chociaż pewne działania podejmował na miejscu ambasador

${ }^{126}$ Więcej zob.: P. Żurek, Bośnia $i$ Hercegowina $w$ wizji politycznej Franjo Tuđmana (1991-1995), [w:] Bośnia i Hercegowina 15 lat po Dayton..., s. 16-17; por.: I. Lučić, Karađorđevo, politički mit ili dogovor?, „Časopis za suvremenu povijest" 2003, vol. 35, no. 1, s. 7-36; K. Nikolić, Slobodan Milošević i Franjo Tuđman o statusu Bosne i Hercegovine 1991, „Istorija 20. veka" 2010 , vol. 28 , br. 3, s. 137-150.

${ }^{127}$ Więcej zob.: M.J. Zacharias, Komunizm..., s. 534; M. Korzeniewska-Wiszniewska, Serbia pod rzadami..., s. 101; A. Izetbegović, Inescapable Questions. Autobiographical Notes, trans. by S. Rissaluddin, J. Izetbegović, Leicester 2003, s. 93-94; V. Katz, Platforma o budućoj jugoslavenskoj zajednici (Plan Izetbegović-Gligorov), Pogled iz bosanskohercegovačke perspektive, „Prilozi” 2013, br. 42, s. 207-226. 
W. Zimmermann ${ }^{128}$. USA zachęcały także do większej aktywności w Jugosławii polityków z Europy ${ }^{129}$. Przedstawiciele administracji amerykańskiej $\mathrm{w}$ dalszym ciagu werbalnie wspierali funkcjonowanie jednolitej federacji jugosłowiańskiej. W lutym 1991 r. James Dobbins z Departamentu Stanu stwierdził, że polityka Stanów Zjednoczonych wobec Jugosławii opiera się na poparciu jedności, demokracji, dialogu, praw człowieka $i$ reform rynkowych, a wybuch konfliktu zbrojnego w Jugosławii może uderzać $w$ nasze nadzieje na nowy okres pokoju, stabilizacji i wspótpracy w Europie ${ }^{130}$.

Pojawiały się w tym czasie kolejne raporty służb specjalnych USA, informujace o niebezpiecznej sytuacji w SFRJ. W analizie CIA ze stycznia 1991 r. ostrzegano, że Jugosławia zmierza w stronę rozpadu, zaś procesowi temu może towarzyszyć użycie siły, a nawet wojna domowa. Według autorów tego raportu, w przypadku konfliktu zbrojnego żadnej ze stron nie uda się w krótkim czasie zwyciężyć w wojnie, która będzie krwawa, chaotyczna $i$ przewlekta ${ }^{131}$. Interwencja armii

${ }^{128}$ O działalności Zimmermanna w tamtym okresie zob. np.: S.L. Szczesio, Polityka Stanów Zjednoczonych Ameryki wobec rozpadu Jugostawii w latach 1990-1991, „Acta Universitatis Lodziensis. Folia Historica” 2009, [nr] 84, s. 167 i nast.; W. Zimmermann, Origins..., s. 122 i nast.

${ }^{129}$ Pod koniec lutego $1991 \mathrm{r}$. jeden z przedstawicieli Departamentu Stanu przybył do kilku stolic europejskich, by zaktywizować Europejczyków do działań na rzecz rozwiązania konfliktu jugosłowiańskiego i zachowania integralności federacji, zob. N. Both, op. cit., s. 83.

${ }^{130}$ Statement of Hon. James F. Dobbins, Principal Deputy Assistant Secretary of State, Bureau of European and Canadian Affairs, [w:] Civil Strife in Yugoslavia: The U.S. Response. Hearing before the Subcommittee on European Affairs of the Committee on Foreign Relations. United States Senate. One hundred second Congress. First Session. February 21, 1991, Washington 1991, s. 76 .

${ }^{131}$ Yugoslavia: Military Dynamics of a Potential Civil War, 23 I 1991, s. 1, http://www.foia.cia.gov (dostęp 12 X 2013). 
federalnej w Chorwacji i Słowenii groziłaby wybuchem starć w Bośni i Hercegowinie, Kosowie oraz Macedonii. W raporcie tym ostrzegano także, że wojna domowa w SFRJ oznaczałaby otwarcie na nowo problemów narodowościowych w innych państwach bałkańskich i zagrożenie dla regionu. Wskazywano równocześnie na możliwość wykorzystania do rozwiązania problemu jugosłowiańskiego instytucji Konferencji Bezpieczeństwa i Współpracy w Europie ${ }^{132}$. Niestety wkrótce okazało się, że amerykańscy analitycy dobrze przewidzieli rozwój wydarzeń w SFRJ. Kolejne raporty wywiadowcze i ostrzeżenia nie zmieniły polityki Waszyngtonu wobec tego regionu, a może dodatkowo były argumentem dla otoczenia prezydenta USA, by pozostawić tę „bałkańską łamigłówkę” europejskim partnerom. W tym czasie administracja Busha koncentrowała się szczególnie na wydarzeniach na Bliskim Wschodzie i operacji przeciwko Husajnowi.

Kryzys w federacji jugosłowiańskiej pogłębił się w maju 1991 r. za sprawą zablokowania przez Serbów wyboru na przewodniczącego Prezydium SFRJ Chorwata, S. Mesicia $^{133}$. W ten sposób Jugosławia pozostawała bez głowy państwa, mimo prób mediacji ze strony A. Markovicia. Poza tym Słoweńcy i Chorwaci już de facto jawnie dażyli do secesji i opuszczenia federacji. Dodatkowo, Serbowie chorwaccy przeprowadzili 12 maja 1991 r. głosowanie, w którym większość uprawnionych opowiedziała się za przyłączeniem do Serbii ${ }^{134}$. Natomiast w referendum w Chorwacji 19 maja 1991 r. aż 94\% głosujących opowiedziało się za

${ }^{132}$ Ibidem, s. 7-8.

${ }^{133}$ D. Bilandžić, Hrvatska moderna povijest, Zagreb 1999, s. 790-791; J. Wojnicki, Proces..., s. 105. Więcej zob. S. Mesić, Demise of Yugoslavia. A Political Memoir, Budapest-New York 2004, s. 19-43.

${ }^{134}$ Zob. S. Wojciechowski, Integracja $i$ dezintegracja Jugosławii na przetomie XXi XXI wieku, Poznań 2002, s. 74. 
niepodległością republiki ${ }^{135}$. Był to kolejny ważny krok, który przybliżył Chorwatów do wyjścia z Jugosławii. Po referendum w Słowenii w grudniu 1990 r. także Chorwacja opowiedziała się za opuszczeniem SFRJ.

Niemal w przeddzień ogłoszenia deklaracji niepodległości przez Słowenię i Chorwację na wizytę w stolicy SFRJ zdecydował się szef dyplomacji Stanów Zjednoczonych. Baker przybył do Belgradu 21 czerwca 1991 r. Spotkał się wówczas z przedstawicielami władz federalnych, wszystkich republik oraz Albańczyków z Kosowa. Jak twierdził, przyjechał, gdyż zdawał sobie sprawę z niebezpieczeństwa rozpadu państwa, co mogłoby mieć bardzo poważne konsekwencje, nie tylko dla Jugosławii, ale i całej Europy ${ }^{136}$. We wspomnieniach napisał, że nie potrafił przekonać do swoich racji większości polityków jugosłowiańskich - wyjątkami byli K. Gligorov i A. Izetbegović $^{137}$. Przywódcy Serbii, Słowenii i Chorwacji potwierdzali brak swego poparcia dla propozycji Gligorova i Izetbegovicia, natomiast prezydent Macedonii przewidywał podczas rozmowy z Bakerem, że w przypadku secesji Chorwatów i Słoweńców dojdzie do krwawej taźni ${ }^{138}$. Amerykanie nie mieli jednak za wiele do zaoferowania przedstawicielom narodów Jugosławii, poza werbalnym wsparciem dla jedności kraju, dla premiera Markovicia oraz dla propozycji prezydentów Macedonii i Bośni. Baker wrócił do Waszyngtonu mocno wstrzaśnięty

${ }^{135}$ J. Wojnicki, Dylematy przeobrażeń ustrojowych $w$ Republice Chorwacji, [w:] Republika Chorwacji. Polityka wewnętrzna $i$ międzynarodowa, pod red. nauk. A. Jagiełło-Szostak, Wrocław 2014, s. 17; D. Bilandžić, op. cit., s. 792. Serbowie chorwaccy zbojkotowali ten plebiscyt.

${ }^{136}$ Secretary of State Baker, Belgrade, Yugoslavia, June 21, 1991 (Excerpts), „Foreign Policy Bulletin” 1991, vol. 2, no. 1, s. 73.

${ }^{137}$ J.A. Baker III (with T.M. DeFrank), op. cit., s. 480. Zob. również R.L. Hutchings, op. cit., s. 310.

${ }^{138}$ W. Zimmermann, Origins..., s. 136. 
i stwierdził, że politycy $\mathrm{w}$ SFRJ nie moga wydostać się $z X V w{ }^{139}$ Lecąc jeszcze $\mathrm{w}$ samolocie napisał do G. Busha, że wizyta $\mathrm{w}$ Belgradzie to jeden $\mathrm{z}$ najbardziej frustrujacych dni na stanowisku sekretarza stanu, i że łatwiej jest osiagnąć porozumienie na Bliskim Wschodzie między przywódcami Syrii i Izraela niż pogodzić S. Miloševicia i F. Tuđmana ${ }^{140}$.

Ostatecznie - pomimo ostrzeżeń Bakera - 25 czerwca 1991 r. Chorwaci i Słoweńcy ogłosili niepodległość. Wkrótce rozpoczęła się wojna w Słowenii, a następnie w Chorwacji. Po kilku miesiacach republiki te zostały uznane przez państwa Europejskiej Wspólnoty Gospodarczej (EWG), a rozpad SFRJ stał się faktem. W tym czasie przestał też istnieć ZSRR. Amerykanie dalej pozostawali na uboczu działań majacych na celu zakończenie rozlewu krwi na Bałkanach, a sekretarz stanu USA wypowiedział sławne zdanie: We don't have a dog in this fight ${ }^{141}$. Wynikało to z postawy Waszyngtonu, a także $\mathrm{z}$ ambicji krajów EWG, które były niechętne włączeniu się Stanów Zjednoczonych do działań dyplomatycznych w Jugosławii, uważając, że kryzys ten powinien zostać rozwiązany przez Europejczyków. Tak się jednak nie stało, a w 1992 r. kolejny konflikt zbrojny rozpoczął się w Bośni i Hercegowinie...

${ }^{139}$ M. Dobbs, Precz $z$ Wielkim Bratem. Upadek imperium radzieckiego, przeł. P. Kwiatkowski, posł. A. Paczkowski, Poznań 1998, s. 515.

${ }^{140}$ J.A. Baker III (with T.M. DeFrank), op. cit., s. 483, 635. O wrażeniach Bakera po zawitych spotkaniach w czerwcu 1991 r. w Jugosławii wspomina także ówczesny premier Wielkiej Brytanii, John Major, który cytuje słowa szefa dyplomacji Stanów Zjednoczonych: I ja myślałem, że Bliski Wschód jest skomplikowany, J. Major, The Autobiography, London 1999, s. 532.

${ }^{141}$ L. Silber, A. Little, Yugoslavia. Death of a Nation, New York-London 1997, s. 201. 